\title{
The nitrogen-potassium intersection: Membranes, metabolism, and mechanism
}

Running title: The N-K intersection

\section{Devrim Coskun, Dev T. Britto, and Herbert J. Kronzucker*}

Department of Biological Sciences and the Canadian Centre for World Hunger Research

(CCWHR), University of Toronto, 1265 Military Trail, Toronto, Ontario, Canada, M1C 1A4

*Corresponding author: herbert.kronzucker@utoronto.ca

Keywords: ammonium, nitrate, influx, efflux, translocation, assimilation, plant productivity

\begin{abstract}
Nitrogen $(\mathrm{N})$ and potassium $(\mathrm{K})$ are the two most abundantly acquired mineral elements by plants and their acquisition pathways interact in complex ways. Here, we review pivotal interactions with respect to root acquisition, storage, translocation, and metabolism, between the $\mathrm{K}^{+}$ion and the two major $\mathrm{N}$ sources, ammonium $\left(\mathrm{NH}_{4}{ }^{+}\right)$and nitrate $\left(\mathrm{NO}_{3}{ }^{-}\right)$. The intersections between $\mathrm{N}$ and $\mathrm{K}$ physiology are explored at a number of organizational levels, from moleculargenetic processes, to compartmentation, to whole plant physiology, and discussed in the context of both N-K cooperation and antagonism. Nutritional regulation and optimization of plant growth, yield, metabolism, and water-use efficiency are also discussed.
\end{abstract}

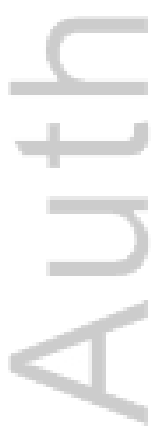

This is the author manuscript accepted for publication and has undergone full peer review but has not been through the copyediting, typesetting, pagination and proofreading process, which may lead to differences between this version and the Version of Record. Please cite this article as doi: 10.1111/pce.12671

This article is protected by copyright. All rights reserved. 


\section{Introduction}

Nitrogen $(\mathrm{N})$ and potassium $(\mathrm{K})$ are required for plants to complete their life cycles, and are the two nutrients acquired in greatest quantities by roots (Oosterhuis et al. 2014). The pathways by which these elements are transported and utilized by plants intersect in significant ways, including the influences exerted by potassium ions on nitrogen nutrition and physiology, and vice versa, in terms of primary uptake of $\mathrm{N}$ and $\mathrm{K}$ at the root plasma membrane, their transport, accumulation, and assimilation within the plant, and the regulation of these metabolic and transport pathways. In this paper we shall review what is known about these interactions, with special emphasis on mechanistic processes and plant productivity.

A few fundamental distinctions between these essential elements should be made at the outset. Firstly, while potassium is generally available to plants only as a simple monoatomic, monovalent cation, $\mathrm{K}^{+}$, nitrogen is available in the form of diverse compounds, e.g. as cationic ammonium $\left(\mathrm{NH}_{4}{ }^{+}\right)$, anionic nitrate $\left(\mathrm{NO}_{3}{ }^{-}\right)$, or as amino acids, which may be cationic, anionic, or zwitterionic, depending on the chemical species and soil $\mathrm{pH}$. In addition, uncharged ammonia, $\mathrm{NH}_{3}$, is likely to rapidly enter plant root cells from the soil, particularly under conditions of high $\mathrm{N}$ supply and/or high $\mathrm{pH}$ (Coskun et al. 2013b). Because the dominant forms of $\mathrm{N}$ available to plants in most soils are the inorganic ions $\mathrm{NH}_{4}{ }^{+}$and $\mathrm{NO}_{3}{ }^{-}$, however, they, with the $\mathrm{K}^{+}$ion, will make up the central focus of our review.

Another distinction is that $\mathrm{K}^{+}$ions, once taken up by plants, remain in this simple ionic state, while $\mathrm{N}$-containing compounds undergo numerous chemical reactions and become covalently bonded within organic molecules throughout the plant. This fundamental difference is reflected in the major physiological roles the two elements play in plants. Nitrogen is an essential constituent of a vast array of metabolites and structural compounds, including proteins, nucleic acids, chlorophyll, co-enzymes, phytohormones, and secondary metabolites, while the main functions of $\mathrm{K}^{+}$are as a major osmolyte and source of positive charge for electrical homeostasis and enzyme activation (Evans \& Wildes 1971; Leigh \& Wyn Jones 1984; Britto \& Kronzucker 
2008; Marschner 2011). Thus, our discussion of the metabolic processes at the intersection of $\mathrm{N}$ and $\mathrm{K}$ physiology will focus on biochemical pathways involving the transformation of nitrogen.

Thirdly, it is interesting that $\mathrm{N}$ enters the terrestrial biosphere chiefly from the atmosphere as a result of enzymatic processes in $\mathrm{N}_{2}$-fixing soil bacteria (and today, via the industrial Haber-Bosch process), although weathering of bedrock N (itself primarily atmospherically derived), which ties up about $20 \%$ of the global $\mathrm{N}$ pool, can sometimes produce ecologically significant rates of nitrogen release (Holloway \& Dahlgren 2002; Xu et al. 2012). By contrast, $\mathrm{K}^{+}$must be replenished by weathering of parent rock and release from exchangeable and non-exchangeable sources, if not supplied as fertilizer (Zhang et al. 2010).

Soil $\mathrm{NH}_{4}{ }^{+}$concentrations tend to range between 0.1 and $1 \mathrm{mM}$, while those of $\mathrm{NO}_{3}{ }^{-}$tend to be higher, often exceeding $1 \mathrm{mM}$ and reaching $10 \mathrm{mM}$ or even higher following fertilization or a burst of nitrification (Wolt 1994; Crawford \& Glass 1998; Owen \& Jones 2001; Miller et al. 2007). Thus, the molar ratios of soil $\mathrm{NO}_{3}{ }^{-}$to $\mathrm{NH}_{4}{ }^{+}$typically range between 10 and 100 (Wolt 1994; Miller et al. 2007). In some soils, however, such as rice paddies, bog lands, and boreal and montane forests, anaerobic, acidic, and reductive conditions reverse this scenario, with $\mathrm{NH}_{4}{ }^{+}$ concentrations exceeding those of $\mathrm{NO}_{3}^{-}$(Gillman \& Bell 1978; Kronzucker et al. 1997, 2000). In the case of $\mathrm{K}^{+}$, soil concentrations tend to be similar to those of $\mathrm{NH}_{4}{ }^{+}$, or about $0.1-1 \mathrm{mM}$ (Wolt 1994; White et al. 2013). In some agricultural areas of the world, including China, India, and the Philippines, the relatively small $\mathrm{K}^{+}$pools are replenished at rates far lower than those of $\mathrm{N}$ replenishment, leading to nutritional imbalances, reduced productivity, and eutrophication by $\mathrm{N}$ runoff (Dobermann et al. 1998; Hoa et al. 2006; Andrist-Rangel et al. 2007; Zhang et al. 2010). The concentrations of $\mathrm{NO}_{3}{ }^{-}, \mathrm{NH}_{4}{ }^{+}$, and $\mathrm{K}^{+}$in soils can vary greatly, not only over regional scales, but even within relatively small patches (Wolt 1994; Miller et al. 2007; Cramer et al. 2009). Nitrate levels also tend to show greater heterogeneity in soils, and can range over two orders of magnitude across relatively short distances (e.g. 4 m or less; Lark et al. 2004), whereas $\mathrm{NH}_{4}{ }^{+}$and $\mathrm{K}^{+}$levels tend to vary more narrowly, about one order of magnitude over a similar scale. This is 
partially due to the negative charge on $\mathrm{NO}_{3}{ }^{-}$, which results in a high degree of mobility within soils (Miller \& Cramer 2004). Plant roots themselves directly increase soil heterogeneity within the rhizosphere via $\mathrm{N}$ - and K-uptake processes, producing zones of depletion (Scherer \& Ahrens 1996; Hinsinger et al. 2005; Kayser \& Isselstein 2005; Moody \& Bell 2006; Andrist-Rangel et al. 2007).

Soil concentrations of $\mathrm{N}$ and $\mathrm{K}$ are important not only because plant productivity can be limited by their scarcity, but also because their excess can bring about toxicity and repress growth. Thus, optimum growth and yield curves, which can vary greatly with plant species and environmental factors, are typically seen with respect to these nutrients (Asher \& Ozanne 1967; MacLeod 1969; Loué 1980; Britto \& Kronzucker 2013). The shapes of such curves can be greatly influenced by the presence of other potentially limiting nutrients. In Fig. 1, this type of influence is shown for $\mathrm{K}$ supply upon $\mathrm{N}$ optima (1A), and vice-versa (1B). It is notable that the lowest provision of $\mathrm{K}(1 \mathrm{~A})$ or $\mathrm{N}(1 \mathrm{~B})$ results in a relatively moderate $\mathrm{N}$ or $\mathrm{K}$ concentration (respectively) required to reach maximum yield (i.e. about $6 \mathrm{mM} \mathrm{N}$, or $70 \mathrm{~kg} \mathrm{ha}^{-1} \mathrm{~K}$ ), but this yield is still much lower than can be reached with higher provision of the companion nutrient.

\section{Transport}

It is rather remarkable that the transport functions involved in the uptake of $\mathrm{NO}_{3}{ }^{-}, \mathrm{NH}_{4}{ }^{+}$, and $\mathrm{K}^{+}$from soil solution, moving these ions across the plasma membrane and into the cytosol of the root cell, share a common feature: all have been characterized using two-mechanism models, which consist of saturable, high-affinity and linear, low-affinity transport systems ("HATS" and "LATS") generally operating at low and high external substrate concentrations, respectively (Miller et al. 2007; Szczerba et al. 2009; Zhang et al. 2010). For the cations $\mathrm{K}^{+}$and $\mathrm{NH}_{4}{ }^{+}$, these two types of transport systems mechanistically contend with the two main thermodynamic scenarios encountered by roots engaged in cation uptake: those that require active uptake (HATS conditions), and those that allow passive uptake (LATS conditions). In general, the active uptake 
of a cationic substrate is driven by an energetic coupling between the passive flow of $\mathrm{H}^{+}$down its transmembrane electrochemical potential gradient, and the substrate's thermodynamically "uphill" influx into the cell, while passive uptake proceeds "downhill" via ion channels (Hedrich \& Schroeder 1989; Szczerba et al. 2009; Coskun et al. 2013a). It is worth noting that the distinction between HATS and LATS transporters is somewhat blurred, and ion channels can at times function at low substrate concentrations, while active-transporting carriers can operate at high concentrations (see below). In the case of $\mathrm{NO}_{3}{ }^{-}$, it is likely that, under most conditions, uptake is thermodynamically active, due to the inside-negative electrical potential difference across the plasma membrane (Wang et al. 2012). The plethora of transport proteins catalyzing the fluxes of $\mathrm{NO}_{3}{ }^{-}, \mathrm{NH}_{4}{ }^{+}$, and $\mathrm{K}^{+}$under both HATS and LATS scenarios, many of which have been identified at the genetic level, is consistent with the spatially and temporally heterogeneous distributions of these substrates in the soil (see Introduction). However, it has been pointed out that the transport of $\mathrm{NO}_{3}{ }^{-}$under many field conditions might be catalyzed primarily by lowaffinity transporters, given the relatively high $\mathrm{NO}_{3}{ }^{-}$concentrations in soils, and because the expression and activities of high-affinity $\mathrm{NO}_{3}{ }^{-}$transporters become downregulated as soil $\left[\mathrm{NO}_{3}{ }^{-}\right]$ rises (Miller et al. 2007).

One of the best known interactions between $\mathrm{N}$ and $\mathrm{K}$ physiology in plants is the marked inhibitory effect that $\mathrm{NH}_{4}{ }^{+}$exerts on the high-affinity $\mathrm{K}^{+}$uptake system (Smith \& Epstein 1964; Deane-Drummond \& Glass 1983; Pettersson et al. 1984; Scherer et al. 1984; Vale et al. 1987, 1988; Wang et al. 1996; Spalding et al. 1999; Nielsen and Schjoerring 1998; Santa-Maria et al. 2000; Szczerba et al. 2008a; ten Hoopen et al. 2010; Coskun et al. 2010, 2013a; Zhang et al. 2010). In barley seedlings, the inhibition of $\mathrm{K}^{+}$translocation to the shoot by $\mathrm{NH}_{4}{ }^{+}$appears to be even more pronounced than the inhibition of primary $\mathrm{K}^{+}$uptake at the plasma membrane, with suppressions as high as 90\% (Kronzucker et al. 2003). This inhibition appears to be at least partially reciprocal, resulting in an "antagonism" between the two ions, with both competitive and non-competitive components. The competitive effects likely arise from the similarities between the two ions, in terms of their hydrated diameters, charge, and influence on membrane 
potentials (Wang et al. 1996; ten Hoopen et al. 2010). Non-competitive effects include a suppression of $\mathrm{NH}_{4}{ }^{+}$uptake in tobacco seedlings by $\mathrm{K}^{+}$that persists even after $\mathrm{K}^{+}$removal (Scherer et al. 1984), the lack of suppression of $\mathrm{NH}_{4}{ }^{+}$uptake by a wide range of external $\left[\mathrm{K}^{+}\right]$in sweet pepper (Xu et al. 2002), a stimulation of $\mathrm{NH}_{4}{ }^{+}$transport by $\mathrm{K}^{+}$in Arabidopsis (ten Hoopen et al. 2010; also see Szczerba et al. 2008b, for a LATS-range stimulation), and the inhibition of $\mathrm{K}^{+}$uptake by the acidification of the rhizosphere that is associated with $\mathrm{NH}_{4}{ }^{+}$uptake in many species (Findenegg 1987). It has also been shown that the induction, by $\mathrm{K}^{+}$starvation, of AtHAK5 (the gene encoding the dominant component of high-affinity $\mathrm{K}^{+}$transport in Arabidopsis roots; Gierth \& Mäser 2007; Rubio et al. 2008; see Fig. 2) expression was almost completely suppressed by the presence of only $100 \mu \mathrm{M} \mathrm{NH}_{4}{ }^{+}$(Qi et al. 2008; cf. Rubio et al. 2008; see Section 3). In another study, it was shown that the removal of $\mathrm{NH}_{4}{ }^{+}$from solutions bathing the roots of barley and Arabidopsis plants resulted in dramatic increases (4.5- and 6-fold in the two species, respectively) in $\mathrm{K}^{+}$uptake (Coskun et al. 2013a). Interestingly, this effect occurred under both low- and high- $\mathrm{K}^{+}$conditions, and was partially attributed to the hyperpolarization of the plasma-membrane electrical potential that was observed upon $\mathrm{NH}_{4}{ }^{+}$ withdrawal.

A lower accumulation of $\mathrm{K}^{+}$in $\mathrm{NH}_{4}{ }^{+}$-grown (relative to $\mathrm{NO}_{3}{ }^{-}$-grown) plants is thus partially attributable to the suppression, by $\mathrm{NH}_{4}{ }^{+}$, of $\mathrm{K}^{+}$influx in the HATS range. However, it may also be due to an enhancement of $\mathrm{K}^{+}$efflux by $\mathrm{NH}_{4}{ }^{+}$, which has been demonstrated in several studies (Munn \& Jackson 1978; Rufty et al. 1982; Topa \& Jackson 1988; Coskun et al. 2010; cf. Deane-Drummond \& Glass 1983). In the study by Coskun et al. (2010), it was shown that $\mathrm{NH}_{4}{ }^{+}$-stimulated $\mathrm{K}^{+}$efflux in roots of barley could be completely counteracted by the channel-blocking agents tetraethylammonium $\left(\mathrm{TEA}^{+}\right)$and cesium $\left(\mathrm{Cs}^{+}\right)$, suggesting that it is catalyzed by an as yet unidentified ion channel, possibly a member of the Shaker family of $\mathrm{K}^{+}$specific channels. This study also showed that $\mathrm{K}^{+}$efflux could be stimulated by the co-presence of $\mathrm{NH}_{4}{ }^{+}$and $\mathrm{NO}_{3}{ }^{-}$(as $\mathrm{NH}_{4} \mathrm{NO}_{3}$ ), but $\mathrm{NO}_{3}{ }^{-}$as the sole $\mathrm{N}$ source reduced $\mathrm{K}^{+}$efflux, an effect also observed by Pettersson (1984). 
A few studies, however, have provided evidence that $\mathrm{NH}_{4}{ }^{+}$can actually stimulate highaffinity $\mathrm{K}^{+}$transport under some conditions (Nieves-Cordones et al. 2008; Alvarez-Pizarroa et al. 2011). These studies have suggested that the stimulation was due to a more electrically hyperpolarized plasma membrane in the presence of $\mathrm{NH}_{4}{ }^{+}$, a condition, however, that is rarely seen in other studies (e.g. Coskun et al. 2013a; see Section 3) Ammonium-induced hyperpolarization was also inferred in sorghum roots based on an increase in expression of the plasma-membrane $\mathrm{H}^{+}$-ATPase (Alvarez-Pizarro et al. 2011), and such a hyperpolarization was measured in roots of tomato (Nieves-Cordones et al. 2008). The latter study suggested that membrane hyperpolarization is a regulatory component of HAK5 expression in tomato (see Section 3).

By contrast, few effects of $\mathrm{NH}_{4}{ }^{+}$on $\mathrm{K}^{+}$transport in the low-affinity range have been reported (cf. Coskun et al. 2013a). However, a study using T-DNA insertion lines showed that transport of $\mathrm{K}^{+}$not only via HAK5 but also via AKT1, the dominant low-affinity $\mathrm{K}^{+}$-specific influx channel in plant roots (Ivashikina et al. 2001; Gierth \& Mäser 2007; Fig. 2), is sensitive to $\mathrm{NH}_{4}{ }^{+}$(Rubio et al. 2008). Nevertheless, the powerful suppression of HAK-mediated $\mathrm{K}^{+}$transport by $\mathrm{NH}_{4}{ }^{+}$, coupled to the lack of such an effect on AKT1, has been used as a parsing tool to distinguish between the two systems. By this means, it was shown that AKT1, normally associated with LATS, is capable of transporting $\mathrm{K}^{+}$at external concentrations as low as $10 \mu \mathrm{M}$ in Arabidopsis (Hirsch et al. 1998; Spalding et al. 1999), and $100 \mu \mathrm{M}$ in barley (Coskun et al. 2013a), given a sufficiently negative membrane potential. The "dual-affinity" nature of AKT1 is not unique; it can also be seen in the Arabidopsis high-affinity $\mathrm{K}^{+}$transporter AtKUP1 (Fu \& Luan 1998) and the $\mathrm{NO}_{3}{ }^{-}$transporter AtNRT1.1, in which a molecular switch between high- and low-affinity functions via changes in phosphorylation and conformational states has been demonstrated (Ho et al., 2009; Sun et al. 2014; Parker \& Newstead 2014; see also Section 3). Nevertheless, some studies have shown effects of $\mathrm{NH}_{4}{ }^{+}$supply on low-affinity $\mathrm{K}^{+}$ transport. Vale et al. (1987) found that both a saturating and a linear phase of $\left[\mathrm{K}^{+}\right]$-dependent $\mathrm{K}^{+}$ transport in corn were suppressed by $\mathrm{NH}_{4}{ }^{+}$, but the latter phase, while kinetically resembling 
"classic" low-affinity transport due to its linearity (Szczerba et al. 2009), was only investigated between 50 and $200 \mu \mathrm{M} \mathrm{K}^{+}$, at which the flux may have still been dominated by HAK systems. An interesting aspect of this study was that the maximal suppression of $\mathrm{K}^{+}$influx was seen at $100 \mu \mathrm{M} \mathrm{NH}_{4}{ }^{+}$, with no further suppression seen at 200-500 $\mu \mathrm{M}$. At higher $\mathrm{K}^{+}$and $\mathrm{NH}_{4}{ }^{+}$ concentrations ( 5 and $10 \mathrm{mM}$, respectively), however, it was clearly demonstrated in a study on barley roots that steady-state $\mathrm{NH}_{4}{ }^{+}$supply can indeed inhibit LATS-range $\mathrm{K}^{+}$transport (Coskun et al. 2013a). In this study, removal of $\mathrm{NH}_{4}{ }^{+}$during measurement of ${ }^{42} \mathrm{~K}^{+}$uptake resulted in a flux more than twice as high as in control plants (i.e. those in the presence of $10 \mathrm{mM} \mathrm{NH}_{4}{ }^{+}$). Moreover, when $\mathrm{NH}_{4}{ }^{+}$was removed and replaced by $\mathrm{NO}_{3}{ }^{-}$(also at $10 \mathrm{mM}$ ), $\mathrm{K}^{+}$influx was more than three times that of controls. Interestingly, the $\mathrm{NH}_{4}{ }^{+}$-withdrawal effect was generally shortterm, and essentially disappeared over a 10 -hr period, while similar experiments at low $\mathrm{K}^{+}(20$ and $100 \mu \mathrm{M}$ ) showed a longer-lasting effect of $\mathrm{NH}_{4}{ }^{+}$withdrawal, resulting in fluxes 4-5 times higher than control, as well as substantially higher $\mathrm{K}^{+}$accumulation, even after $24 \mathrm{hr}$. This suggests that under some conditions, such as that of low $\mathrm{K}^{+}$supply, the influence of other ions on $\mathrm{K}^{+}$transport may override regulation by internal $\mathrm{K}^{+}$status or growth demands. Under other conditions, the reverse may be true, and $\mathrm{K}^{+}$uptake and content may be relatively unaffected by the supply of other nutrients (including N), as has been frequently observed (Pitman 1972; Pettersson et al. 1984; Vale et al. 1987; Zhang et al. 2010).

At least one study has reported the stimulation of low-affinity $\mathrm{K}^{+}$uptake under steadystate provision of high $(10 \mathrm{mM}) \mathrm{NH}_{4}{ }^{+}$, relative to equimolar $\mathrm{NO}_{3}{ }^{-}$(Szczerba et al. 2008b). At or below $100 \mu \mathrm{M} \mathrm{K}^{+}$, the characteristic suppression of $\mathrm{K}^{+}$influx by $\mathrm{NH}_{4}{ }^{+}$was observed in this study, but, at $1.5 \mathrm{mM} \mathrm{K}^{+}$and above, growth on $\mathrm{NH}_{4}{ }^{+}$pronouncedly stimulated both $\mathrm{K}^{+}$influx and accumulation in the shoots of rice plants. Because of the upregulation of $\mathrm{NH}_{4}{ }^{+}$transport known to occur under high $\mathrm{NH}_{4}{ }^{+}$conditions (e.g. Wang et al. 1993; Rawat et al. 1999; Cerezo et al. 2001), it was suggested that the stimulation of $\mathrm{K}^{+}$transport under these conditions was mediated by the enhanced activity of a low-affinity $\mathrm{NH}_{4}{ }^{+}$transporter. However, it should be noted that this effect was found in tropical lowland rice, considered to be an "ammonium 
specialist", and might not be common among species sensitive to $\mathrm{NH}_{4}{ }^{+}$toxicity. Moreover, the increased $\mathrm{K}^{+}$accumulation found under $\mathrm{NH}_{4}{ }^{+}$nutrition in rice did not always translate into increased growth; maximal growth was found at $1.5 \mathrm{mM} \mathrm{K}^{+}$, but growth declined by $40 \%$ when $\mathrm{K}^{+}$was raised to $40 \mathrm{mM}$ (the condition at which the largest stimulation of $\mathrm{NH}_{4}{ }^{+}$transport and accumulation was observed). Under $\mathrm{NO}_{3}{ }^{-}$nutrition, the optimal growth concentration was even lower, with a fresh-weight decline of about $20 \%$ observed at $1.5 \mathrm{mM} \mathrm{K}^{+}$(relative to $100 \mu \mathrm{M}$ ) despite the higher shoot $\mathrm{K}^{+}$content in these plants.

It is well known that $\mathrm{NH}_{4}{ }^{+}$nutrition is often associated with substantial declines in tissue levels of essential cations including $\mathrm{K}^{+}$as well as $\mathrm{Ca}^{2+}$ and $\mathrm{Mg}^{2+}$ (Kirkby \& Knight 1977; Kurvits \& Kirkby 1980; van Beusichem et al. 1988); this is a central aspect of the $\mathrm{NH}_{4}{ }^{+}$toxicity syndrome, and is largely attributable to the inhibition of fluxes of other cations by $\mathrm{NH}_{4}{ }^{+}(\mathrm{Britto}$ \& Kronzucker 2002). The converse of this is that $\mathrm{NH}_{4}{ }^{+}$toxicity is frequently found to be relieved by an increase in $\mathrm{K}^{+}$provision (Lips et al. 1990; Cao et al. 1993; Britto \& Kronzucker 2002; ten Hoopen et al. 2010). In addition, elevated $\mathrm{K}^{+}$provision can reduce the inhibition of $\mathrm{NO}_{3}{ }^{-}$ transport by $\mathrm{NH}_{4}{ }^{+}$, when $\mathrm{N}$ is provided as $\mathrm{NH}_{4} \mathrm{NO}_{3}$, and improve growth on this mixed-N source (Rufty et al. 1982; Hagin et al. 1990). The alleviation of $\mathrm{NH}_{4}{ }^{+}$toxicity by $\mathrm{K}^{+}$is in part a result of the upregulation, by increased $\mathrm{K}^{+}$, of enzymes involved in $\mathrm{NH}_{4}{ }^{+}$assimilation (see Section 4), but also because of the pronounced, dose-dependent reductions in low-affinity $\mathrm{NH}_{4}{ }^{+}$transport and accumulation brought about by elevated $\mathrm{K}^{+}$(Szczerba et al. 2008a, b; Balkos et al. 2010). This contrasts with high-affinity $\mathrm{NH}_{4}{ }^{+}$uptake via the AMT1 transporter (possibly involving a $\mathrm{H}^{+}-$ $\mathrm{NH}_{4}{ }^{+}$symport mechanism; Ortiz-Ramirez et al. 2011; Xu et al. 2012), which appears to be quite selective for $\mathrm{NH}_{4}{ }^{+}$and against $\mathrm{K}^{+}$(Ninnemann et al. 1994). At high $(10 \mathrm{mM}) \mathrm{NH}_{4}{ }^{+}$, however, a switch in external $\left[\mathrm{K}^{+}\right]\left(\left[\mathrm{K}^{+}\right]_{\text {ext }}\right)$ from 0.1 to $1.5 \mathrm{mM}$ reduced $\mathrm{NH}_{4}{ }^{+}$influx into barley roots by nearly 60\% (Szczerba et al. 2008a), with similar results seen in rice (Szczerba et al. 2008b; Balkos et al. 2010). In addition, elevated $\left[\mathrm{K}^{+}\right]_{\text {ext }}$ reduced the efflux of $\mathrm{NH}_{4}{ }^{+}$from roots of barley and rice, to an even greater extent than influx, resulting in a lower extent of futile $\mathrm{N}$ cycling across the plasma membrane, which has been linked to $\mathrm{NH}_{4}{ }^{+}$toxicity (Britto et al. 2001; Chen et 
al. 2013). Interestingly, these effects were seen both instantaneously and over the long term, and, although $\mathrm{K}^{+}$elevation did not generally reduce the net flux of $\mathrm{NH}_{4}{ }^{+}$into the plant (indeed, it was substantially increased in rice), the increased metabolism of $\mathrm{NH}_{4}{ }^{+}$resulted in greatly reduced accumulation of this toxic compound (of up to 75-80\%) in both barley and rice (Szczerba et al. 2008a; Balkos et al. 2010). Subsequent work has shown that, under these low-affinity $\mathrm{NH}_{4}{ }^{+}-$ transport conditions, the major transported species may in fact be the deprotonated, uncharged ammonia molecule $\left(\mathrm{NH}_{3}\right)$, which crosses the plasma membrane via aquaporins (Jahn et al. 2004; Coskun et al. 2013b). The ability of elevated $\left[\mathrm{K}^{+}\right]_{\mathrm{ext}}$ to greatly diminish transport via aquaporins may reflect the significance of this ion in the area of plant water relations (Quintero et al. 2007; Britto et al. 2014; see below).

In contrast to the antagonistic relationship between $\mathrm{K}^{+}$and $\mathrm{NH}_{4}{ }^{+}$nutrition, the acquisition rates of $\mathrm{K}^{+}$and $\mathrm{NO}_{3}{ }^{-}$are often found to be positively correlated, and enhance one another, likely because of improved charge balance (Minotti et al. 1968; Blevins et al. 1974; Kirkby \& Knight 1977; Kurvits \& Kirkby 1980; Pettersson et al. 1984; Kochian et al. 1985; Le Bot \& Kirkby 1991; Macduff et al.1997; Marschner et al. 1996; Siebrecht \& Tischner 1999; Coskun et al. 2013a; Delaire et al. 2014) and the activation, by $\mathrm{K}^{+}$, of enzymes involved in $\mathrm{NO}_{3}{ }^{-}$assimilation (Hagin et al. 1990; Zhang et al. 2010; Roosta \& Schjoerring 2009; Balkos et al. 2010; see Section 4). Thus, it is commonly observed that plants take up and accumulate substantially more $\mathrm{K}^{+}$under $\mathrm{NO}_{3}{ }^{-}$nutrition than with $\mathrm{NH}_{4}{ }^{+}$, or in the presence of other cations such as $\mathrm{Mg}^{2+}, \mathrm{Na}^{+}$, and $\mathrm{Ca}^{2+}$ (Ivashikina \& Feyziev 1998; Coskun et al. 2013a). However, the direct influences exerted by one ion on the transport of the other are poorly understood. Nitrate and potassium can both be stored in the vacuole at high concentrations (Martinoia et al. 1981; 2007; Walker et al. 1996; Oosterhuis et al. 2014), where they may electrically balance one another, and can be dynamically retrieved according to plant demand (Blumwald \& Poole 1985; Walker et al. 1996). The situation for $\mathrm{NH}_{4}{ }^{+}$in the vacuole is less clear. It is not often accumulated in high amounts in plant tissues, except under toxic conditions, under which it may enter the vacuole as $\mathrm{NH}_{3}$, via aquaporins (Jahn et al. 2004; Loqué et al. 2005; Martinoia et al. 2007; Coskun et al. 2013). 
An intriguing example of the co-operative use of $\mathrm{K}^{+}$and $\mathrm{NO}_{3}{ }^{-}$in plants is what is referred to as the "Dijkshoorn-Ben Zioni model" of internal ion cycling via the vasculature, in which $\mathrm{NO}_{3}{ }^{-}$is transported from root to shoot in the xylem, using $\mathrm{K}^{+}$as a counterion (Dijkshoorn et al. 1968; Ben Zioni et al. 1971; Kirkby \& Knight 1977; Pettersson 1984; Touraine et al. 1988; Fig. $3 \mathrm{~A}) . \mathrm{NO}_{3}{ }^{-}$is reduced and assimilated into amino acids in the shoot, with the concomitant transfer of negative charge to organic (carboxylic) acids. These acids, particularly in the form of malate, are then transported to the roots via the phloem, accompanied by $\mathrm{K}^{+}$as counterion, where they are decarboxylated and release $\mathrm{HCO}_{3}{ }^{-}$to the external medium. Indeed, it has been estimated that as much as half the $\mathrm{K}^{+}$found in the xylem stream is not directly introduced via uptake processes in the root, but comes from recirculated $\mathrm{K}^{+}$in the phloem (Engels \& Kirkby 2001; Chérel et al. 2014).

The Dijkshoorn-Ben Zioni model has proven useful in a large number of studies, and provides one of the few mechanisms known to link shoot demand for nutrients with their uptake by the roots (Casadesús et al. 1995; Marschner et al. 1996). However, its applicability is limited by several conditions, and has been contradicted in some studies. First, the model pertains to plants that reduce $\mathrm{NO}_{3}{ }^{-}$mainly in the shoot, which is a common but by no means universal occurrence (Pate, 1973; Andrews, 1986; Touraine et al. 1990). Interestingly, a low supply of $\mathrm{K}^{+}$ can increase the degree of $\mathrm{NO}_{3}{ }^{-}$reduction in roots relative to shoots, possibly due to the lack of a xylem-mobile cation to accompany $\mathrm{NO}_{3}{ }^{-}$moving to the shoot (Rufty et al. 1981 ; Forster \& Jeschke 1993; see Section 4). Second, even when shoot reduction is pronounced, and the upward movement of $\mathrm{K}^{+}$as a counterion with $\mathrm{NO}_{3}{ }^{-}$is observed, a significant downward recirculation of K-malate in the phloem is not always seen (Kirkby and Knight 1977). This appears to be related to conditions where there is a balanced uptake of cations and anions by roots, as in many herbaceous dicotyledons growing under nutrient-replete conditions (van Egmond 1978; $c f$. Touraine et al. 1990). Third, the regulation of diurnal variations in $\mathrm{NO}_{3}{ }^{-}$uptake may depend less on the synthesis, transport, or addition of malate than on light-dark transitions affecting the shoot (Delhon et al. 1996; also see Casadesús et al. 1995; Fig. 3B). 
Nevertheless, in many cases, the model appears to be fairly robust in terms of the coordinated translocation of the two ions from root to shoot. Significant progress in this area includes demonstrations of $\mathrm{K}^{+}$and $\mathrm{NO}_{3}{ }^{-}$interdependence at the molecular level, in terms of alterations of transporters that load $\mathrm{NO}_{3}{ }^{-}$into the xylem, and resulting effects on $\mathrm{K}^{+}$translocation (Lin et al. 2008; Xia et al. 2015; see Section 3). However, it may be possible for other cations, in particular $\mathrm{Mg}^{2+}$, to at least partially substitute for $\mathrm{K}^{+}$in the charge balancing of $\mathrm{NO}_{3}{ }^{-}$in the xylem (Forster \& Jeschke 1993). In addition, there appears to be a regulatory decoupling between the uptake of $\mathrm{K}^{+}$and $\mathrm{NO}_{3}{ }^{-}$across the plasma membrane, on the one hand, and their translocation to the shoot (Kirkby \& Armstrong 1980; Touraine \& Grignon 1982; Casadesús et al. 1995; Ivashikina \& Feyziev 1998).

\section{Sensing, Signaling, and Co-regulation}

Plants have evolved complex sensing, signaling, and regulatory mechanisms to manage the acquisition of ions in fluctuating environments, and key similarities can be found in mechanisms involving $\mathrm{K}^{+}$and $\mathrm{N}$ transport and assimilation. These similarities include the coregulation at the transcriptional level of $\mathrm{K}^{+}$on $\mathrm{N}$ transporters and vice versa, the posttranslational modifications of $\mathrm{K}^{+}$and $\mathrm{N}$ transporters by the same regulatory proteins, as well as more systemic changes, such as in membrane potential, the accumulation of reactive oxygen species (ROS), and phytohormones.

One of the clearest examples of K-N interaction at the transport level, i.e. the inhibition of high-affinity $\mathrm{K}^{+}$transport via HAK transporters by $\mathrm{NH}_{4}{ }^{+}$(see Section 2; Fig. 2), manifests itself at the transcriptional level as well. $\mathrm{NH}_{4}{ }^{+}$has been shown to downregulate AtHAK5 and CaHAK 1 transcription in $\mathrm{K}^{+}$-deprived Arabidopsis and pepper plants, respectively (MartínezCordero et al. 2005; Qi et al. 2008). It is well documented that $\mathrm{K}^{+}$deprivation leads to hyperpolarization of the root plasma membrane (Etherton \& Higinbotham 1960; Maathuis \& Sanders 1993; Amtmann et al. 2006; Schachtman \& Shin 2007; Britto \& Kronzucker 2008). It 
has recently been suggested, based on a correlation analysis, that membrane hyperpolarization could trigger an as yet unknown signaling cascade inducing the expression of high-affinity HAK transporters (LeHAK5 and AtHAK5 in tomato and Arabidopsis, respectively; Nieves-Cordones et al. 2008; Rubio et al. 2014). Interestingly, this induction appears to occur even under $\mathrm{K}^{+}$-replete conditions, contrary to reports indicating that HAK induction is dependent on $\mathrm{K}^{+}$starvation (Armengaud et al. 2004; Gierth \& Mäser 2007; Qi et al. 2008). One such condition that has been tested is that of $\mathrm{NO}_{3}{ }^{-}$deprivation, in which membrane hyperpolarization was seen to coincide with an increased expression of AtHAK5 and LeHAK5 (Rubio et al. 2014; see also Wang et al. 2001; Shin et al. 2005). Perhaps critically, however, it does not coincide with increased root (net) $\mathrm{K}^{+}$uptake, in contrast to $\mathrm{K}^{+}$-deprivation conditions, suggesting a specific regulatory role of low $\mathrm{K}^{+}$in HAK5 activity (Rubio et al. 2014). Also intriguingly, Nieves-Cordones et al. (2008) found that tomato plants grown in the presence of $\mathrm{NH}_{4}{ }^{+}$displayed hyperpolarized membrane potentials relative to $\mathrm{NH}_{4}{ }^{+}$-free conditions and increased LeHAK5 expression. This is in apparent contradiction to many reports of $\mathrm{NH}_{4}{ }^{+}$-induced membrane depolarization, at least in the short term (Ullrich et al. 1984; Ayling 1993; Wang et al. 1994). In tomato, transcript levels of LeHAK5 were also found to quickly (2-6 h) decline with membrane-depolarization events (e.g. $\mathrm{K}^{+}$re-supply, or initial exposure to $\mathrm{NH}_{4}^{+}, \mathrm{Rb}^{+}$, vanadate, or CCCP; Nieves-Cordones et al. 2008). It would be interesting to see whether other means of short-term membrane hyperpolarization (e.g. with bicarbonate (Poole 1969), fusicoccin (Ullrich \& Novacky 1990), or $\mathrm{NH}_{4}{ }^{+}$withdrawal from $\mathrm{NH}_{4}{ }^{+}$-grown plants (Coskun et al. 2013a; see above)) would also result in increased HAK5 expression. Overall, this is an interesting, but as yet speculative, regulatory mechanism that requires further investigation.

Another important link between $\mathrm{K}^{+}$and $\mathrm{N}$ nutrition is the involvement of calcineurin Blike (CBL)-interacting protein kinase 23 (CIPK23) in high-affinity $\mathrm{K}^{+}$and $\mathrm{NO}_{3}{ }^{-}$uptake $(\mathrm{Xu}$ et al. 2006; Ho et al. 2009; Castaings et al. 2011; Tsay et al. 2011; see also Fig. 2). CIPK23 is involved in activating high-affinity uptake of both $\mathrm{K}^{+}$and $\mathrm{NO}_{3}{ }^{-}$via AKT1 and NPF6.3 (NRT1.1), respectively (Xu et al. 2006; Cheong et al. 2007; Lee et al. 2007; Li et al. 2006; Ho et 
al. 2009). Under $\mathrm{K}^{+}$deprivation, a $\mathrm{Ca}^{2+}$ signaling cascade (triggered perhaps by ethylene and ROS; see below) results in its binding to CBL1 and CBL9, which in turn activate CIPK23, which phosphorylates and thus activates AtAKT1 (Xu et al. 2006; Cheong et al. 2007; Li et al. 2006; Lee et al. 2007; Luan et al. 2009; Wang and Wu 2013). Like AtAKT1, AtNPF6.3 is a dualaffinity transporter, conducting both high- and low-affinity $\mathrm{NO}_{3}{ }^{-}$uptake (Wang et al. 1998; Liu et al. 1998; Liu \& Tsay 2003; Ho et al. 2009; Tsay et al. 2011; Léran et al. 2014). At low external nitrate concentrations (i.e. HATS conditions), the same signaling cascade triggers AtCIPK23 to phosphorylate AtNPF6.3 (at T101), and thus switches the transporter into 'highaffinity mode' (Ho et al. 2009; Sun et al. 2014; Parker \& Newstead 2014). By contrast, unphosphorylated AtNPF6.3 functions as a low-affinity transporter (Hu et al. 2009). The crystal structure of AtNPF6.3 (AtNRT1.1) and the allosteric effects of phosphorylation have been determined (Sun et al. 2014; Parker \& Newstead 2014); to our knowledge, such a study has yet to be conducted for AKT1. Recently, a developmental role of the CBL1-CBL9-CIPK23AKT1/NRT1.1 signaling module was proposed, identifying specific parameters related to root system architecture as targets (Kellermeier et al. 2014). For example, it was found that under $\mathrm{K}^{+}$ and $\mathrm{NO}_{3}{ }^{-}$deficiency, phosphorylated AKT1 and NRT1.1 stimulate second-order lateral root emergence. This is an important new development since conditions arise that exclude AKT1 and NRT1.1 in high-affinity $\mathrm{K}^{+}$and $\mathrm{NO}_{3}{ }^{-}$uptake, respectively (e.g. under conditions where highaffinity HAK transporters are functional (Rubio et al. 2008; Coskun et al. 2013a, 2014) or where high-affinity NRT2 transporters predominate (Okamoto et al. 2003; Wang et al. 2012)).

The apparent coupling of $\mathrm{K}^{+}$and $\mathrm{NO}_{3}{ }^{-}$transport in the xylem (Section 2) appears to play out at the molecular level as well. In $n r t 1.5$ knock-out mutants for a transporter responsible for xylem $\mathrm{NO}_{3}{ }^{-}$loading in Arabidopsis, $\mathrm{K}^{+}$translocation was reduced along with that of $\mathrm{NO}_{3}{ }^{-}(\mathrm{Lin}$ et al. 2008). However, a $\mathrm{K}^{+}$-coupled mechanism for this transporter was ruled out in a heterologous expression system in favour of one of $\mathrm{H}^{+}$coupling. Furthermore, $\mathrm{K}^{+}$deprivation was shown to downregulate the expression of AtNRT1.5 (AtNPF7.3), suggesting $\mathrm{NO}_{3}{ }^{-}$translocation was controlled by plant $\mathrm{K}^{+}$levels (Lin et al. 2008). Similar results were found in rice with respect to 
the nitrate transporter OsNPF2.4 (Xia et al. 2015), and other nitrate transporters have been implicated in $\mathrm{NO}_{3}{ }^{-}$xylem loading (e.g. AtNPF6.3 (AtNRT1.1), AtNPF2.3; OsNPF2.2, and LeNRT2.3; Léran et al. 2013; Taochy et al. 2015; Li et al. 2015; Fu et al. 2015), but their relationships to $\mathrm{K}^{+}$nutrition have yet to be elucidated. The expression of the gene for the $\mathrm{K}^{+}$ xylem-loading transporter SKOR was shown to be upregulated by nitrate supply (Wang et al. 2004), demonstrating a similar response as AtNRT1.5 and OsNPF2.4 to $\mathrm{K}^{+}$supply. These data strongly support a co-regulation at the level of xylem transport that maintains the balance between $\mathrm{NO}_{3}{ }^{-}$and $\mathrm{K}^{+}$(Wang et al. 2012). It will be interesting to see if such co-regulation at the molecular level exists at the level of primary uptake, where, for example, the stimulation of lowaffinity $\mathrm{K}^{+}$uptake in the presence of $\mathrm{NO}_{3}{ }^{-}$is observed (Kochian et al. 1985; Coskun et al. 2013a; see Section 2; Fig. 2).

In addition to nutritional regulation, $\mathrm{K}^{+}$and $\mathrm{NO}_{3}{ }^{-}$xylem-loading transporters and root-toshoot translocation also show diurnal regulation (Fig. 3B). AtNPF7.3 (AtNRT1.5) expression peaked at the night-to-day transition and fell to a minimum at the day-to-night transition (Lin $e t$ al. 2008). In the legume Samanea saman, SPORK1 (a SKOR homolog) expression showed similar diel patterns (Moshelion et al. 2002). Such patterns are consistent with xylem loading of $\mathrm{NO}_{3}{ }^{-}$and $\mathrm{K}^{+}$being highest during the day and lowest during the night (Mattson et al. 1988; Schurr \& Schulze 1995; Macduff \& Bakken 2003; Siebrecht et al. 2003), as they are closely tied to transpiration rates (Le Bot \& Kirkby 1992; Siebrecht et al. 2003; Fig. 3C). Moreover, leaf nitrate reductase (NR) activity (the first enzyme involved in nitrate reduction; Campbell 1999) also rises to a maximum during the first half of the light period (Scheible et al. 1997; Lillo et al. 2001). This highly suggests a coordinated and concerted mechanism at play related to $\mathrm{NO}_{3}{ }^{-}$and $\mathrm{K}^{+}$translocation. Insight into the underlying signaling and regulatory network is eagerly anticipated.

$\mathrm{K}^{+}$deprivation has been demonstrated to result in strong upregulation of the nitrate transporters LeNRT1.2 and LeNRT2.1 in tomato roots (Wang et al. 2001). This parallels the well- 
documented effects of the induction of high-affinity HAK transporters in response to $\mathrm{K}^{+}$ deprivation (Martínez-Cordero et al. 2005; Gierth \& Mäser, 2007; Qi et al. 2008). By contrast, $\mathrm{K}^{+}$deprivation resulted in the downregulation of AtNRT2.1, as well as AtNRT2.3, and AtNRT2.6, in Arabidopsis (Armengaud et al. 2004). Expression of AtNRT1.1, however, was upregulated with $\mathrm{K}^{+}$deprivation in this study. To our knowledge, these discrepancies have yet to be thoroughly investigated or resolved. However, the differences may be the result of varying timeframes of $\mathrm{K}^{+}$deficiency in each study, as the responses observed for tomato were made over a relatively short time (within 1-3 h), whereas the responses observed for Arabidopsis took place after 2 weeks of $\mathrm{K}^{+}$starvation (although re-supply of $\mathrm{K}^{+}$resulted in AtNRT2 genes being upregulated within 6 h; Armengaud et al. 2004). Nevertheless, these reports clearly indicate a "crosstalk" between the nutritional status of one nutrient and the expression of membrane transporters for the other.

Another common observance to $\mathrm{K}^{+}$and $\mathrm{NO}_{3}{ }^{-}$deficiency is the accumulation of ROS as a signaling component (Shin \& Schachtman 2004; Shin et al. 2005; Schachtman \& Shin 2007). While the consequences of ROS accumulation are not well understood (Schachtman \& Shin 2007), they include the upregulation of AtHAK5 and AtNRT2.1 expression under $\mathrm{K}^{+}$and $\mathrm{NO}_{3}{ }^{-}$deprivation, respectively (Shin et al. 2005; Kim et al. 2010, 2012). In contrast to the study by Armengaud et al. (2004), AtNRT2.1 expression was not affected by $\mathrm{K}^{+}$deprivation in the study by Shin et al. (2005). This may also be due to timing, as $\mathrm{K}^{+}$deprivation was maintained for up to $30 \mathrm{~h}$ in the latter study, as opposed to 2 weeks in the former. A more comprehensive study on the role of ROS in this crosstalk would be most interesting. $\mathrm{Ca}^{2+}$ may be part of this signaling cascade both upstream (Torres \& Dangl 2005; Li et al. 2006; Lebaudy et al. 2007) and downstream (Mori \& Schroeder 2004) of ROS production. At least in the case of $\mathrm{K}^{+}$deprivation, ethylene acts upstream of ROS (Shin \& Schachtman 2004; Jung et al. 2009). Mutants defective in ethylene or ROS production, such as ethylene insensitive2-1 (ein2-1), an NADPH oxidase (rhd2), or a type III peroxidase (rci3), all showed reduced AtHAK5 expression (Shin \& 
Schachtman 2004; Jung et al. 2009; Kim et al. 2010; Fig. 2). The expression and function of nitrate transporters in these mutants, however, remain unknown.

\section{Metabolism}

Although $\mathrm{K}^{+}$itself is not metabolized, it plays a vital role in many aspects of plant metabolism. $\mathrm{K}^{+}$is involved in the activity of some 46 enzymes (Evans \& Sorger 1966; Leigh \& Wyn Jones 1984; Hagin et al. 1990; Britto \& Kronzucker 2008; Armengaud et al. 2009), including as cofactor to such critical enzymes as pyruvate kinase, starch synthase, Rubisco, and nitrate reductase (NR; Beevers \& Hageman 1969; Sorger et al. 1965; Evans \& Sorger 1966; Nitsos \& Evans 1966; 1969; Peoples \& Koch 1979; Wyn Jones \& Pollard 1983). Moreover, K ${ }^{+}$ is crucial to protein synthesis, not only with respect to enzyme activation, but also to ribosome synthesis and mRNA turnover (Blevins 1985; Evans \& Wildes 1971; Pettigrew 2008). Its importance in cellular metabolism is reflected in its high, homeostatically set concentration in the cytosol of $\sim 100$ mM (Leigh \& Wyn Jones 1984; Walker et al. 1996; Kronzucker et al. 2003).

The close relationships between $\mathrm{K}^{+}$supply and $\mathrm{N}$ metabolism is evident from many studies. One such connection involves the partitioning of NR activity between the root and shoot (Blevins et al. 1978; Barneix \& Breteler 1985; Förster \& Jeschke 1993; Casadesús et al. 1995; Armengaud et al. 2009), which also depends on plant species, external nitrate supply, temperature, and light intensity (Pate 1973; Smirnoff \& Stewart 1985; Andrews 1986). Generally, with high external $\mathrm{K}^{+}$supply, the co-translocation of $\mathrm{K}^{+}$and $\mathrm{NO}_{3}{ }^{-}$to the shoot increases (Ben Zioni et al. 1971; Blevins et al. 1978; see Section 2; Fig. 3), and both storage of $\mathrm{NO}_{3}{ }^{-}$and $\mathrm{NR}$ activity increase in leaves, while less $\mathrm{N}$ assimilation is found in roots (Blevins $e t$ al. 1978; Rufty et al. 1981). In contrast, with $\mathrm{K}^{+}$deprivation, less translocation of $\mathrm{NO}_{3}{ }^{-}$is observed and hence higher $\mathrm{N}$ assimilation occurs in roots (Förster and Jeschke 1993; Rufty et al. 1981; Wang et al. 2003). Interestingly, this has not been borne out in the model species Arabidopsis thaliana; Armengaud et al. (2009) observed significant decreases in root NR 
activity, relative to $\mathrm{K}^{+}$sufficiency, with prolonged (2-week) $\mathrm{K}^{+}$deprivation. By contrast, the authors observed significant upregulation in the activity of key enzymes involved in ammonium assimilation, i.e. glutamine synthetase (GS), ferredoxin-glutamine-2-oxoglutarate aminotransferase (Fd-GOGAT), and glutamate dehydrogenase (GDH). It was concluded that the downregulation of NR (as well as nitrate transporters; Armengaud et al. 2004), could be as a result of decreased carbon-skeleton production via the TCA cycle (decreased glycolysis and the direct inhibition of pyruvate kinase due to low cytoplasmic $\mathrm{K}^{+}$, was observed). On the other hand, the upregulation of GS, GOGAT, and GDH was interpreted as a compensatory response to maintain $\mathrm{C}$ flux through the TCA cycle and into amino acids and proteins (increased NADPmalic enzyme activity due to low cytoplasmic $\mathrm{pH}$ was also observed).

In rice, root GS activity was found to increase with increasing $\left[\mathrm{K}^{+}\right]_{\mathrm{ext}}$ (again, in apparent contradiction to the Arabidopsis model; see above), reaching its maximum at $5 \mathrm{mM}$ in an $\mathrm{NH}_{4}{ }^{+}$ (10 mM) background (Balkos et al. 2010). The same pattern was also observed for phosphoenolpyruvate carboxylase (PEPC) activity, the key anapleurotic C-fixing enzyme, as well as with total protein content (Fig. 4). This corresponded with tremendous gains in plant biomass, with growth $160 \%$ higher than $\mathrm{NO}_{3}{ }^{-}$-grown plants and $220 \%$ higher than plants grown at $0.1 \mathrm{mM} \mathrm{K}^{+}$(Balkos et al. 2010). Similar effects were observed in cucumber, although they were not as dramatic, which may reflect the lower tolerance to $\mathrm{NH}_{4}{ }^{+}$in this species, relative to rice (Roosta \& Schjoerring 2008). Other reports of the stimulation of expression and activity of $\mathrm{N}$-assimilatory enzymes by $\mathrm{K}^{+}$can be found in Ali et al. (1991) and Mohammad \& Naseem (2006). Taken together, these findings, including the controversial findings with Arabidopsis (above), point to a distinct reprogramming, by $\mathrm{K}^{+}$, of $\mathrm{C}$ and $\mathrm{N}$ metabolism (Armengaud et al. 2009; Balkos et al. 2010; Pettigrew 2008). A similar reconfiguration of primary (and secondary) metabolic machinery was observed by transcriptomic analysis in Arabidopsis, in response to N. After two days of $\mathrm{N}$ deprivation, the majority of genes associated with photosynthesis, chlorophyll synthesis, and plastid protein synthesis were repressed, and those associated with secondary metabolism were induced (Scheible et al. 2004). 
Lastly, phytohormone responses involving $\mathrm{K}^{+}$and $\mathrm{N}$ nutrition include auxin and cytokinin (CK) biosynthesis and signaling. Cao et al. (1993) showed that growth suppression of Arabidopsis seedling roots in the presence of $6 \mathrm{mM} \mathrm{NH}_{4}{ }^{+}$and $20 \mu \mathrm{M} \mathrm{K}^{+}$could be relieved by elevation of $\mathrm{K}^{+}$to $200 \mu \mathrm{M}$, but not in the presence of supplementary auxin (indole acetic acid) or cytokinin (6-benzylaminopurine), or a combination of the two. Moreover, growth suppression by $\mathrm{NH}_{4}{ }^{+}$was also much less pronounced in auxin-resistant mutants. Cytokinins have been implicated in $\mathrm{K}^{+}$and $\mathrm{N}$ signaling and the regulation of genes encoding $\mathrm{K}^{+}$and $\mathrm{N}$ transporters (Brenner et al. 2005; Kiba et al. 2005; Schachtman \& Shin, 2007; Shin 2011; Nam et al. 2012). Under low- $\mathrm{K}^{+}$stress, root $\mathrm{CK}$ levels are reduced, which result in ROS accumulation, root hair growth, and AtHAK5 expression (Nam et al. 2012). Similarly, low N results in lowered CK levels (Takeiet al. 2002, 2004; Scheible et al. 2004; Miyawaki et al. 2006; Nam et al. 2012) which have been linked to increased expression of genes encoding nitrate and ammonium transporters (NRT2 and AMT1, respectively; Brenner et al. 2005; Kiba et al.2005).

\section{Conclusion}

On a planet where the human population continues to greatly expand (forecasts estimates growth of up to 12.3 billion by 2100 ; Gerland et al. 2014), ever-increasing demands on the world's agricultural systems are expected to produce immense strains on land, water, and nutrient resources in the coming decades. Rapidly changing climates and environmental degradation in many parts of the world will put additional stresses on crop production, while a dangerous feed-forward cycle may play itself out, given that food systems are themselves responsible for 19-29\% of anthropogenic greenhouse gas emissions globally (Vermeulen et al. 2012). Plant physiologists have applied their knowledge and skills to produce remarkable increases in crop yields over the past century, preventing the starvation of millions, and must be called upon once again to address new challenges. 
Clearly, to reduce the amount of new land required to meet growing demands, and thereby reduce strains upon "marginal" or ecologically fragile environments, the efficiency of crop production will need to be increased. One approach to this would be to precisely determine species- and site-specific growth optima with respect to nutrients such as $\mathrm{NO}_{3}{ }^{-}, \mathrm{NH}_{4}{ }^{+}$, and $\mathrm{K}^{+}$, not only singly, but in relation to one another. In this review, we have discussed some of the key physiological issues pertaining to these relationships, from the often observed antagonism between $\mathrm{NH}_{4}{ }^{+}$and $\mathrm{K}^{+}$, to the alleviation of $\mathrm{NH}_{4}{ }^{+}$toxicity by $\mathrm{K}^{+}$, to the co-operative uptake, internal transport, and utilization of $\mathrm{NO}_{3}{ }^{-}$and $\mathrm{K}^{+}$. Other interactions, such as those involving synergies and antagonisms between $\mathrm{NO}_{3}{ }^{-}$and $\mathrm{NH}_{4}{ }^{+}$, and their relationships to $\mathrm{K}^{+}$supply, as well as interactions involving other essential macro- and micronutrients in optimizing growth and yield, will greatly improve the science of plant nutrition. In addition, the examination of nutrient interactions with water use in plants (and its efficiency), such as the influences of $\mathrm{NO}_{3}{ }^{-}$and $\mathrm{K}^{+}$ on aquaporin and stomatal function (Guo et al. 2003; Cramer et al. 2009; Fig. 2), and as major osmotica, will become increasingly important as water scarcity and soil salinity become more widespread. Moreover, the world's most important crop species, rice, is also the world's most water consumptive, further highlighting the necessity to understand and optimize plant water use (Hoekstra \& Chapagain 2007; Chapagain \& Hoekstra 2011; Britto et al. 2014).

While the complexities of nutrient sensing, signaling mechanisms, and transport regulation cannot be fully unraveled without the benefits of molecular biology, there is still much room for physiological methods in the pursuit of more efficient and productive crop systems (Pettigrew 2008; Cramer et al. 2009; Britto et al. 2014). This is important in part because of the current public reaction against recombinant DNA technology, particularly in Europe. However, even while "genetically modified" crop plants are out of favour, the vast amount of data provided by modern molecular biology (e.g. Armengaud et al. 2009) has the potential to inform and direct physiologists and agronomists seeking to improve crop production by nutritional means. These approaches, combined with gradual improvements in remote and local sensing of soil fertility 
and crop mineral content, and in spatially and temporally precise application of water and nutrients, can help bring about yield increases even in GMO-free zones.

\section{Acknowledgements}

Funding was provided by the Natural Sciences and Engineering Research Council of Canada (NSERC).
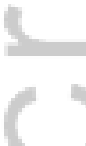

$\infty$
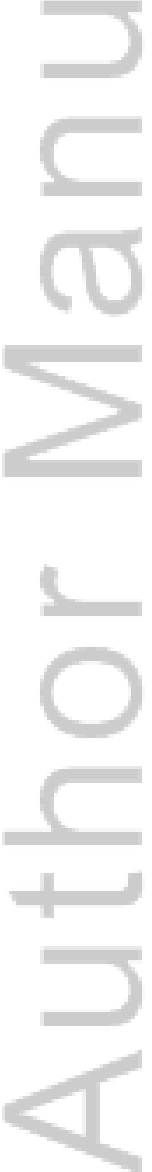

This article is protected by copyright. All rights reserved. 


\section{References}

Ali A.A., Ikeda M., Yamada Y. (1991) Effects of the supply of K, Ca, and Mg on the absorption and assimilation of ammonium-nitrogen and nitrate-nitrogen in tomato plants. Soil Science \& Plant Nutrition 37, 283-289.

Alvarez-Pizarro J.C., Gomes-Filho E., Prisco J.T., Grossi-de-Sá M.F., de Oliveira-Neto O.B. (2011) $\mathrm{NH}_{4}{ }^{+}$-stimulated low- $\mathrm{K}^{+}$uptake is associated with the induction of $\mathrm{H}^{+}$extrusion by the plasma membrane $\mathrm{H}^{+}$-ATPase in sorghum roots under $\mathrm{K}^{+}$deficiency. Journal of Plant Physiology 168, 1617-1626.

Amtmann A., Hammond J.P., Armengaud P., White P.J. (2006) Nutrient sensing and signalling in plants: potassium and phosphorus. Advances in Botanical Research 43, 209-257.

Andrews M. (1986) The partitioning of nitrate assimilation between root and shoot of higher plants. Plant, Cell \& Environment 9, 511-519.

Andrist-Rangel Y., Edwards A.C., Hillier S., Öborn I. (2007) Long-term K dynamics in organic and conventional mixed cropping systems as related to management and soil properties. Agriculture, Ecosystems \& Environment 122, 413-426.

Armengaud P., Breitling R., Amtmann A. (2004) The potassium-dependent transcriptome of Arabidopsis reveals a prominent role of jasmonic acid in nutrient signaling. Plant Physiology 136, 2556-2576.

Armengaud P., Sulpice R., Miller A.J., Stitt M., Amtmann A., Gibon Y. (2009) Multilevel analysis of primary metabolism provides new insights into the role of potassium nutrition for glycolysis and nitrogen assimilation in Arabidopsis roots. Plant Physiology 150, 772 785.

Asher C.J., Ozanne P.G. (1967) Growth and potassium content of plants in solution cultures maintained at constant potassium concentrations. Soil Science 103, 155-161. 
Ayling S.M. (1993). The effect of ammonium ions on membrane potential and anion flux in roots of barley and tomato. Plant, Cell \& Environment 16, 297-303.

Balkos K.D., Britto D.T., Kronzucker H.J. (2010) Optimization of ammonium acquisition and metabolism by potassium in rice (Oryza sativa L. cv. IR-72). Plant, Cell \& Environment 33, 23-34.

Barneix A.J., Breteler H. (1985) Effect of cations on uptake, translocation and reduction of nitrate in wheat seedlings. New Phytologist 99, 367-379.

Beevers L., Hageman R.H. (1969) Nitrate reduction in higher plants. Annual Review of Plant Physiology 20, 495-522.

Ben Zioni A., Vaadia Y., Herman Lips S. (1971) Nitrate uptake by roots as regulated by nitrate reduction products of the shoot. Physiologia Plantarum 24, 288-290.

Blevins D.G. (1985) Role of potassium in protein metabolism in plants. Potassium in Agriculture 413-424.

Blevins D.G., Barnett N.M., Frost W.B. (1978) Role of potassium and malate in nitrate uptake and translocation by wheat seedlings. Plant Physiology 62, 784-788.

Blevins D.G., Hiatt A.J., Lowe R.H. (1974) The influence of nitrate and chloride uptake on expressed sap $\mathrm{pH}$, organic acid synthesis, and potassium accumulation in higher plants. Plant Physiology 54, 82-87.

Blumwald E., Poole R.J. (1985) Nitrate storage and retrieval in Beta vulgaris: Effects of nitrate and chloride on proton gradients in tonoplast vesicles. Proceedings of the National Academy of Sciences, USA 82, 3683-3687.

Brenner W.G., Romanov G.A., Köllmer I., Bürkle L., Schmülling T. (2005) Immediate-early and delayed cytokinin response genes of Arabidopsis thaliana identified by genome-wide

This article is protected by copyright. All rights reserved. 
expression profiling reveal novel cytokinin-sensitive processes and suggest cytokinin action through transcriptional cascades. Plant Journal 44, 314-333.

Britto D.T., Balkos K.D., Becker A., Coskun D., Huynh W.Q., Kronzucker H.J. (2014) Potassium and nitrogen poising: Physiological changes and biomass gains in rice and barley. Canadian Journal of Plant Science 94, 1085-1089.

Britto D.T., Kronzucker H.J. (2002) $\mathrm{NH}_{4}{ }^{+}$toxicity in higher plants: a critical review. Journal of Plant Physiology 159, 567-584.

Britto D.T., Kronzucker H.J. (2008) Cellular mechanisms of potassium transport in plants. Physiologia Plantarum 133, 637-650.

Britto D.T., Kronzucker H.J. (2013) Ecological significance and complexity of N-source preference in plants. Annals of Botany 112, 957-963.

Britto D.T., Siddiqi M.Y., Glass A.D.M., Kronzucker H.J. (2001) Futile transmembrane $\mathrm{NH}_{4}{ }^{+}$ cycling: a cellular hypothesis to explain ammonium toxicity in plants. Proceedings of the National Academy of Sciences, USA 98, 4255-4258.

Campbell W.H. (1999) Nitrate reductase structure, function and regulation: bridging the gap between biochemistry and physiology. Annual Review of Plant Biology 50, 277-303.

Cao Y., Glass A.D., Crawford N.M. (1993) Ammonium inhibition of Arabidopsis root growth can be reversed by potassium and by auxin resistance mutations auxl, axrl, and axr2. Plant Physiology 102, 983-989.

Casadesús J., Tapia L., Lambers H. (1995) Regulation of $\mathrm{K}^{+}$and $\mathrm{NO}_{3}{ }^{-}$fluxes in roots of sunflower (Helianthus annuus) after changes in light intensity. Physiologia Plantarum 93, 279-285.

This article is protected by copyright. All rights reserved. 
Castaings L., Marchive C., Meyer C., Krapp A. (2011) Nitrogen signalling in Arabidopsis: how to obtain insights into a complex signalling network. Journal of Experimental Botany 62, 1391-1397.

Cerezo M., Tillard P., Gojon A., Primo-Millo E., Garcia-Agustin P. (2001) Characterization and regulation of ammonium transport systems in Citrus plants. Planta 214, 97-105.

Chapagain A.K., Hoekstra A.Y. (2011) The blue, green and grey water footprint of rice from production and consumption perspectives. Ecological Economics 70, 749-758.

Chen G., Guo S., Kronzucker H.J., Shi W.M. (2013) Nitrogen use efficiency (NUE) in rice links to $\mathrm{NH}_{4}{ }^{+}$toxicity and futile $\mathrm{NH}_{4}{ }^{+}$cycling in roots. Plant and Soil 369, 351-363.

Chérel I., Lefoulon C., Boeglin M., Sentenac H. (2014) Molecular mechanisms involved in plant adaptation to low $\mathrm{K}^{+}$availability. Journal of Experimental Botany 65, 833-848.

Cheong Y. H., Pandey G.K., Grant J.J., Batistic O., Li L., Kim B.G., ..., Luan S. (2007) Two calcineurin B-like calcium sensors, interacting with protein kinase CIPK23, regulate leaf transpiration and root potassium uptake in Arabidopsis. Plant Journal 52, 223-239.

Coskun D., Britto D.T., Li M., Oh S., Kronzucker H.J. (2013a) Capacity and plasticity of potassium channels and high-affinity transporters in roots of barley and Arabidopsis. Plant Physiology 162, 496-511.

Coskun D., Britto D.T., Li M., Becker A., Kronzucker H.J. (2013b) Rapid ammonia gas transport accounts for futile transmembrane cycling under $\mathrm{NH}_{3} / \mathrm{NH}_{4}{ }^{+}$toxicity in plant roots. Plant Physiology 163, 1859-1867.

Coskun D., Britto D.T., Kronzucker H.J. (2010) Regulation and mechanism of potassium release from barley roots: an in planta ${ }^{42} \mathrm{~K}^{+}$analysis. New Phytologist 188, 1028-1038.

Cramer M.D., Hawkins H-J., Verboom G.A. (2009) The importance of nutritional regulation of plant water flux. Oecologia 161, 15-24.

This article is protected by copyright. All rights reserved. 
Crawford N.M., Glass A.D. (1998) Molecular and physiological aspects of nitrate uptake in plants. Trends in Plant Science 3, 389-395.

Deane-Drummond C.E., Glass A.D. (1983) Short term studies of nitrate uptake into barley plants using ion-specific electrodes and ${ }^{36} \mathrm{ClO}_{3}{ }^{-}$II. Regulation of $\mathrm{NO}_{3}{ }^{-}$efflux by $\mathrm{NH}_{4}{ }^{+}$. Plant Physiology 73, 105-110.

Delaire M., Mauget J-C., Beaujard F. (2014) Evidence for a strong correlation between seasondependent nitrate and potassium uptake in two deciduous trees. Trees 28, 769-776.

Delhon P., Gojon A., Tillard P., Passama L. (1996) Diurnal regulation of $\mathrm{NO}_{3}{ }^{-}$uptake in soybean plants III. Implication of the Dijkshoorn-Ben Zioni model in relation with the diurnal changes in $\mathrm{NO}_{3}{ }^{-}$assimilation. Journal of Experimental Botany 47, 885-892.

Dijkshoorn W., Lathwell D.J., De Wit C.T. (1968) Temporal changes in carboxylate content of ryegrass with stepwise change in nutrition. Plant and Soil 29, 369-390.

Dobermann A., Cassman K.G., Mamaril C.P., Sheehy J.E. (1998) Management of phosphorus, potassium, and sulfur in intensive, irrigated lowland rice. Field Crops Research 56, 113138.

Engels C., Kirkby E.A. (2001) Cycling of nitrogen and potassium between shoot and roots in maize as affected by shoot and root growth. Journal of Plant Nutrition and Soil Science 164, 183-191.

Etherton B., Higinbotham N. (1960) Transmembrane potential measurements of cells of higher plants as related to salt uptake. Science 131, 409-410.

Evans H.J., Sorger G.J. (1966) Role of mineral elements with emphasis on the univalent cations. Annual Review of Plant Physiology 17, 47-76.

Evans H.J., Wildes R.A. (1971) Potassium and its role in enzyme activation. In Proc. 8th Colloq. Int. Potash Inst. Bern (pp. 13-39). 
Findenegg G.R. (1987) A comparative study of ammonium toxicity at different constant $\mathrm{pH}$ of the nutrient solution. Plant and Soil 103, 239-243.

Förster J.C., Jeschke W. D. (1993) Effects of potassium withdrawal on nitrate transport and on the contribution of the root to nitrate reduction in the whole plant. Journal of Plant Physiology 141, 322-328.

Fu H.H., Luan S. (1998) AtKUP1: a dual-affinity $\mathrm{K}^{+}$transporter from Arabidopsis. Plant Cell 10, 63-73.

Fu Y., Yi H., Bao J., Gong J. (2015) LeNRT2.3 functions in nitrate acquisition and long-distance transport in tomato. FEBS Letters 589, 1072-1079.

Gerland P., Raftery A.E., Ševčíková H., Li N., Gu D., Spoorenberg T., ..., Wilmoth J. (2014) World population stabilization unlikely this century. Science 346, 234-237.

Gierth M., Mäser P. (2007) Potassium transporters in plants-involvement in $\mathrm{K}^{+}$acquisition, redistribution and homeostasis. FEBS Letters 581, 2348-2356.

Gillman G.P., Bell L.C. (1978) Soil solution studies on weathered soils from tropical North Queensland. Australian Journal of Soil Research 16, 67-77.

Guo F.Q., Young J., Crawford N.M. (2003) The nitrate transporter AtNRT1.1 (CHL1) functions in stomatal opening and contributes to drought susceptibility in Arabidopsis. Plant Cell 15, 107-117.

Hagin J., Olsen S.R., Shaviv A. (1990) Review of interaction of ammonium-nitrate and potassium nutrition of crops. Journal of Plant Nutrition 13, 1211-1226.

Hedrich R., Schroeder J.I. (1989) The physiology of ion channels and electrogenic pumps in higher plants. Annual Review of Plant Physiology 40, 539-569.

This article is protected by copyright. All rights reserved. 
Hinsinger P., Gobran G.R., Gregory P.J., Wenzel W.W. (2005) Rhizosphere geometry and heterogeneity arising from root-mediated physical and chemical processes. New Phytologist 168, 293-303.

Hirsch R.E., Lewis B.D., Spalding E.P., Sussman M.R. (1998) A role for the AKT1 potassium channel in plant nutrition. Science 280, 918-921.

Ho C.H., Lin S.H., Hu H.C., Tsay Y.F. (2009) CHL1 functions as a nitrate sensor in plants. Cell 138, 1184-1194.

Ho C.H., Tsay Y.F. (2010) Nitrate, ammonium, and potassium sensing and signaling. Current Opinion in Plant Biology 13, 604-610.

Hoa N.M., Janssen B.H., Oenema O., Dobermann A. (2006) Comparison of partial and complete soil K budgets under intensive rice cropping in the Mekong Delta, Vietnam. Agriculture, Ecosystems \& Environment 116, 121-131.

Hoekstra A.Y., Chapagain A.K. (2007) Water footprints of nations: water use by people as a function of their consumption pattern. Water Resources Management 21, 35-48.

Holloway J.M., Dahlgren R.A. (2002) Nitrogen in rock: occurrences and biogeochemical implications. Global Biogeochemical Cycles 16, 65-1.

Ivashikina N.V., Feyziev Y.M. (1998) Regulation of nitrate uptake in maize seedlings by accompanying cations. Plant Science 131, 25-34.

Ivashikina N., Becker D., Ache P., Meyerhoff O., Felle H.H., Hedrich R. (2001) K ${ }^{+}$channel profile and electrical properties of Arabidopsis root hairs. FEBS Letters 508, 463-469.

Jahn T.P., Møller A.L., Zeuthen T., Holm L.M., Klærke D.A., Mohsin B., ..., Schjoerring J.K. (2004) Aquaporin homologues in plants and mammals transport ammonia. FEBS Letters 574, 31-36.

This article is protected by copyright. All rights reserved. 
Jung J.Y., Shin R., Schachtman D.P. (2009) Ethylene mediates response and tolerance to potassium deprivation in Arabidopsis. Plant Cell 21, 607-621.

Jungk A., Claassen N. (1986) Availability of phosphate and potassium as the result of interactions between root and soil in the rhizosphere. Zeitschrift für Pflanzenernährung und Bodenkunde 149, 411-427.

Kayser M., Isselstein J. (2005) Potassium cycling and losses in grassland systems: a review. Grass and Forage Science 60, 213-224.

Kellermeier F., Armengaud P., Seditas T.J., Danku J., Salt D.E., Amtmann A. (2014) Analysis of the root system architecture of Arabidopsis provides a quantitative readout of crosstalk between nutritional signals. Plant Cell 26, 1480-1496.

Kiba T., Naitou T., Koizumi N., Yamashino T., Sakakibara H., Mizuno T. (2005) Combinatorial microarray analysis revealing Arabidopsis genes implicated in cytokinin responses through the His $\rightarrow$ Asp phosphorelay circuitry. Plant and Cell Physiology 46, 339-355.

Kim M.J., Ciani S., Schachtman D.P. (2010) A peroxidase contributes to ROS production during Arabidopsis root response to potassium deficiency. Molecular Plant 3, 420-427.

Kirkby E.A., Armstrong M.J. (1980) Nitrate uptake by roots as regulated by nitrate assimilation in the shoot of castor oil plants. Plant Physiology 65, 286-290.

Kirkby E.A., Knight A.H. (1977) Influence of the level of nitrate nutrition on ion uptake and assimilation, organic acid accumulation and catanion balance in whole tomato plants. Plant Physiology 60, 249-253.

Kirkby E.A., Mengel K. (1967) Ionic balance in different tissues of the tomato plant in relation to nitrate, urea, or ammonium nutrition. Plant Physiology 42, 6-14.

Kochian L.V., Xin-Zhi J., Lucas W.J. (1985) Potassium transport in corn roots IV. Characterization of the linear component. Plant Physiology 79, 771-776. 
Kronzucker H.J., Britto D.T. (2011) Sodium transport in plants: a critical review. New Phytologist 189, 54-81.

Kronzucker H.J., Glass A.D.M., Siddiqi M.Y., Kirk G.J.D. (2000) Comparative kinetic analysis of ammonium and nitrate acquisition by tropical lowland rice: implications for rice cultivation and yield potential. New Phytologist 145, 471-476.

Kronzucker H.J., Schjoerring J.K., Erner Y., Kirk G.J., Siddiqi M.Y., Glass A.D.M. (1998)

Dynamic interactions between root $\mathrm{NH}_{4}{ }^{+}$influx and long-distance $\mathrm{N}$ translocation in rice: insights into feedback processes. Plant and Cell Physiology 39, 1287-1293.

Kronzucker H.J., Siddiqi M.Y., Glass A.D. (1997) Conifer root discrimination against soil nitrate and the ecology of forest succession. Nature 385, 59-61.

Kronzucker H.J., Szczerba M.W., Britto D.T. (2003) Cytosolic potassium homeostasis revisited: ${ }^{42} \mathrm{~K}$-tracer analysis in Hordeum vulgare L. reveals set-point variations in [K $\mathrm{K}^{+}$. Planta 217, 540-546.

Kurvits A., Kirkby E.A. (1980) The uptake of nutrients by sunflower plants (Helianthus annum) growing in a continuous flowing culture system, supplied with nitrate or ammonium as nitrogen source. Zeitschrift für Pflanzenernährung und Bodenkunde 143, 140-149.

Lark R.M., Milne A.E., Addiscott T.M., Goulding K.W.T., Webster C.P., O'Flaherty S. (2004) Scale-and location-dependent correlation of nitrous oxide emissions with soil properties: an analysis using wavelets. European Journal of Soil Science 55, 611-627.

Lebaudy A., Véry A.A., Sentenac H. (2007) $\mathrm{K}^{+}$channel activity in plants: genes, regulations and functions. FEBS Letters 581, 2357-2366.

Le Bot J., Kirkby E.A. (1992) Diurnal uptake of nitrate and potassium during the vegetative growth of tomato plants. Journal of Plant Nutrition 15, 247-264.

This article is protected by copyright. All rights reserved. 
Lee S.C., Lan W.Z., Kim B.G., Li L., Cheong Y.H., Pandey G.K., ..., Luan S. (2007) A protein phosphorylation/dephosphorylation network regulates a plant potassium channel. Proceedings of the National Academy of Sciences, USA 104, 15959-15964.

Leigh R.A., Wyn Jones R.G. (1984) A hypothesis relating critical potassium concentrations for growth to the distribution and functions of this ion in the plant cell. New Phytologist 97, $1-13$.

Léran S., Edel K.H., Pervent M., Hashimoto K., Corratgé-Faillie C., Offenborn J.N., ..., Lacombe B. (2015) Nitrate sensing and uptake in Arabidopsis are enhanced by ABI2, a phosphatase inactivated by the stress hormone abscisic acid. Science Signaling $\mathbf{8}$, ra43.

Léran S., Muños S., Brachet C., Tillard P., Gojon A., Lacombe B. (2013) Arabidopsis NRT1.1 is a bidirectional transporter involved in root-to-shoot nitrate translocation. Molecular Plant 6, 1984-1987.

Léran S., Varala K., Boyer J.C., Chiurazzi M., Crawford N., Daniel-Vedele F., ..., Lacombe B. (2014) A unified nomenclature of NITRATE TRANSPORTER 1/PEPTIDE TRANSPORTER family members in plants. Trends in Plant Science 19, 5-9.

Li L., Kim B.G., Cheong Y.H., Pandey G.K., Luan S. (2006) $\mathrm{A} \mathrm{Ca}^{2+}$ signaling pathway regulates a $\mathrm{K}^{+}$channel for low-K response in Arabidopsis. Proceedings of the National Academy of Sciences, USA 103, 12625-12630.

Li Y., Ouyang J., Wang Y.Y., Hu R., Xia K., Duan J., ..., Zhang M. (2015) Disruption of the rice nitrate transporter OsNPF2.2 hinders root-to-shoot nitrate transport and vascular development. Scientific Reports 5, 9635

Lillo C., Meyer C., Ruoff P. (2001) The nitrate reductase circadian system. The central clock dogma contra multiple oscillatory feedback loops. Plant Physiology 125, 1554-1557.

This article is protected by copyright. All rights reserved. 
Lin S.H., Kuo H.F., Canivenc G., Lin C.S., Lepetit M., Hsu P.K., ..., Tsay Y.F. (2008) Mutation of the Arabidopsis NRT1. 5 nitrate transporter causes defective root-to-shoot nitrate transport. Plant Cell 20, 2514-2528.

Lips S.H., Leidi E.O., Silberbush M., Soares M.I.M., Lewis O.E.M. (1990) Physiological aspects of ammonium and nitrate fertilization. Journal of Plant Nutrition 13, 1271-1289.

Liu K.H., Huang C.Y., Tsay Y.F. (1999) CHL1 is a dual-affinity nitrate transporter of Arabidopsis involved in multiple phases of nitrate uptake. Plant Cell 11, 865-874.

Liu K.H., Tsay Y.F. (2003) Switching between the two action modes of the dual-affinity nitrate transporter CHL1 by phosphorylation. EMBO Journal 22, 1005-1013.

Loqué D., Ludewig U., Yuan L., von Wirén N. (2005) Tonoplast Intrinsic Proteins AtTIP2;1 and AtTIP2;3 facilitate $\mathrm{NH}_{3}$ transport into the vacuole. Plant Physiology 137, 671-680.

Loué A. (1980) The interaction of potassium with other growth factors, particularly with other nutrients. Potassium Fertilization in Agricultural Practice. IPI Research Topics 8, 67-93.

Luan S. (2009) The CBL-CIPK network in plant calcium signaling. Trends in Plant Science 14, $37-42$.

Maathuis F.J., Sanders D. (1993) Energization of potassium uptake in Arabidopsis thaliana. Planta 191, 302-307.

Macduff J.H., Bakken A.K., Dhanoa M.S. (1997) An analysis of the physiological basis of commonality between diurnal patterns of $\mathrm{NH}_{4}{ }^{+}, \mathrm{NO}_{3}{ }^{-}$and $\mathrm{K}^{+}$uptake by Phleum pratense and Festuca pratensis. Journal of Experimental Botany 48, 1691-1701.

MacLeod L.B. (1969) Effects of N, P, and K and their interactions on the yield and kernel weight of barley in hydroponic culture. Agronomy Journal 61, 26-29.

This article is protected by copyright. All rights reserved. 
Marschner H., Kirkby E.A., Cakmak I. (1996) Effect of mineral nutritional status on shoot-root partitioning of photoassimilates and cycling of mineral nutrients. Journal of Experimental Botany 47, 1255-1263.

Marschner H. (2011) Marschner's mineral nutrition of higher plants. Academic Press.

Martínez-Cordero M.A., Martínez V., Rubio F. (2005) High-affinity $\mathrm{K}^{+}$uptake in pepper plants. Journal of Experimental Botany 56, 1553-1562.

Martinoia E., Heck U., Wiemken A. (1981) Vacuoles as storage compartments for nitrate in barley leaves. Nature 289, 292-294.

Martinoia E., Maeshima M., Ekkehard H.E. (2007) Vacuolar transporters and their essential role in plant metabolism. Journal of Experimental Botany 58, 83-102.

Mattson W.J., Palmer S.R. (1988). Changes in levels of foliar minerals and phenolics in trembling aspen, Populus tremuloides, in response to artificial defoliation. In Mechanisms of woody plant defenses against insects (pp. 157-169). Springer New York.

Mengel K., Viro M., Hehl G. (1976) Effect of potassium on uptake and incorporation of ammonium-nitrogen of rice plants. Plant and Soil 44, 547-558.

Miller A.J., Cramer M.D. (2004) Root nitrogen acquisition and assimilation. Plant and Soil 274, $1-36$.

Miller A.J., Fan X., Orsel M., Smith S.J., Wells D.M. (2007) Nitrate transport and signalling. Journal of Experimental Botany 58, 2297-2306.

Minotti P.L., Williams D.C., Jackson W.A. (1968) Nitrate uptake and reduction as affected by calcium and potassium. Soil Science Society of America Journal 32, 692-698.

This article is protected by copyright. All rights reserved. 
Miyawaki K., Tarkowski P., Matsumoto-Kitano M., Kato T., Sato S., Tarkowska D., ...,

Kakimoto T. (2006) Roles of Arabidopsis ATP/ADP isopentenyltransferases and tRNA isopentenyltransferases in cytokinin biosynthesis. Proceedings of the National Academy of Sciences, USA 103, 16598-16603.

Mohammad F., Naseem U. (2006) Effect of K application on leaf carbonic anhydrase and nitrate reductase activities, photosynthetic characteristics, $\mathrm{NPK}$ and $\mathrm{NO}_{3}{ }^{-}$contents, growth and yield of mustard. Photosynthetica 44, 471-473.

Moody P.W., Bell M.J. (2006) Availability of soil potassium and diagnostic soil tests. Soil Research 44, 265-275.

Mori I.C., Schroeder J.I. (2004) Reactive oxygen species activation of plant $\mathrm{Ca}^{2+}$ channels. A signaling mechanism in polar growth, hormone transduction, stress signaling, and hypothetically mechanotransduction. Plant Physiology 135, 702-708.

Moshelion M., Becker D., Czempinski K., Mueller-Roeber B., Attali B., Hedrich R., Moran N. (2002) Diurnal and circadian regulation of putative potassium channels in a leaf moving organ. Plant Physiology 128, 634-642.

Munn D.A., Jackson W.A. (1978) Nitrate and ammonium uptake by rooted cuttings of sweet potato. Agronomy Journal 70, 312-316.

Nam Y.J., Tran L.S.P., Kojima M., Sakakibara H., Nishiyama R., Shin R. (2012) Regulatory roles of cytokinins and cytokinin signaling in response to potassium deficiency in Arabidopsis. PLoS ONE 7, e47797

Nielsen K.H., Schjoerring J.K. (1998) Regulation of apoplastic $\mathrm{NH}_{4}{ }^{+}$concentration in leaves of oilseed rape. Plant Physiology 118, 1361-1368.

This article is protected by copyright. All rights reserved. 
Nieves-Cordones M., Miller A.J., Alemán F., Martínez V., Rubio F. (2008) A putative role for the plasma membrane potential in the control of the expression of the gene encoding the tomato high-affinity potassium transporter HAK5. Plant Molecular Biology 68, 521-532.

Ninnemann O., Jauniaux J.C., Frommer W.B. (1994) Identification of a high affinity $\mathrm{NH}_{4}{ }^{+}$ transporter from plants. EMBO Journal 13, 3464-3471.

Nitsos R.E., Evans H.J. (1966) Effects of univalent cations on the inductive formation of nitrate reductase. Plant Physiology 41, 1499-1504.

Okamoto M., Vidmar J.J., Glass A.D.M. (2003) Regulation of NRT1 and NRT2 gene families of Arabidopsis thaliana: responses to nitrate provision. Plant and Cell Physiology 44, 304317.

Oosterhuis D.M., Loka D.A., Kawakami E.M., Pettigrew W.T. (2014) The physiology of potassium in crop production. Advances in Agronomy 126, 203-233.

Ortiz-Ramirez C., Mora S.I., Trejo J., Pantoja O. (2011) PvAMT1;1, a highly selective ammonium transporter that functions as $\mathrm{H}^{+} / \mathrm{NH}_{4}{ }^{+}$symporter. The Journal of Biological Chemistry 286, 31113-31122.

Ourry A., Macduff J.H., Prudhomme M.P., Boucaud J. (1996) Diurnal variation in the simultaneous uptake and 'sink' allocation of $\mathrm{NH}_{4}{ }^{+}$and $\mathrm{NO}_{3}{ }^{-}$by Lolium perenne in flowing solution culture. Journal of Experimental Botany 47, 1853-1863.

Owen A.G., Jones D.L. (2001) Competition for amino acids between wheat roots and rhizosphere microorganisms and the role of amino acids in plant $\mathrm{N}$ acquisition. Soil Biology and Biochemistry 33, 651-657.

Parker J.L., Newstead S. (2014) Molecular basis of nitrate uptake by the plant nitrate transporter NRT1. 1. Nature 507, 68-72.

This article is protected by copyright. All rights reserved. 
Pate J.S. (1973) Uptake, assimilation and transport of nitrogen compounds by plants. Soil Biology and Biochemistry 5, 109-119.

Peoples T.R., Koch D.W. (1979) Role of potassium in carbon dioxide assimilation in Medicago sativa L. Plant Physiology 63, 878-881.

Pettersson S. (1984) Effects of nitrate on influx, efflux and translocation of potassium in young sunflower plants. Physiologia Plantarum 61, 663-669.

Pettigrew W.T. (2008) Potassium influences on yield and quality production for maize, wheat, soybean and cotton. Physiologia Plantarum 133, 670-681.

Pitman M.G. (1972) Uptake and transport of ions in barley seedlings III. Correlation between transport to the shoot and relative growth rate. Australian Journal of Biological Sciences 25, 905-920.

Poole R.J. (1969). Carrier-mediated potassium efflux across the cell membrane of red beet. Plant Physiology 44, 485-490.

Qi Z., Hampton C.R., Shin R., Barkla B.J., White P.J., Schachtman D.P. (2008) The high affinity $\mathrm{K}^{+}$transporter AtHAK5 plays a physiological role in planta at very low $\mathrm{K}^{+}$ concentrations and provides a caesium uptake pathway in Arabidopsis. Journal of Experimental Botany 59, 595-607.

Quintero J.M., Fournier J.M., Benlloch M. (2007) $\mathrm{Na}^{+}$accumulation in shoot is related to water transport in $\mathrm{K}^{+}$-starved sunflower plants but not in plants with a normal $\mathrm{K}^{+}$ status. Journal of Plant Physiology 164, 60-67.

Rawat S.R., Silim S.N., Kronzucker H.J., Siddiqi M.Y., Glass A.D.M. (1999) AtAMT1 gene expression and $\mathrm{NH}_{4}{ }^{+}$uptake in roots of Arabidopsis thaliana: Evidence for regulation by root glutamine levels. Plant Journal 19, 143-152.

This article is protected by copyright. All rights reserved. 
Roosta H.R., Schjoerring J.K. (2008) Effects of nitrate and potassium on ammonium toxicity in cucumber plants. Journal of Plant Nutrition 31, 1270-1283.

Rubio F., Fon M., Ródenas R., Nieves-Cordones M., Alemán F., Rivero R.M., Martínez V. (2014) A low $\mathrm{K}^{+}$signal is required for functional high-affinity $\mathrm{K}^{+}$uptake through HAK5 transporters. Physiologia Plantarum 152, 558-570.

Rubio F., Nieves-Cordones M., Alemán F., Martínez V. (2008) Relative contribution of AtHAK5 and AtAKT1 to $\mathrm{K}^{+}$uptake in the high-affinity range of concentrations. Physiologia Plantarum 134, 598-608.

Rufty T.W., Jackson W.A., Raper C.D. (1981) Nitrate reduction in roots as affected by the presence of potassium and by flux of nitrate through the roots. Plant Physiology 68, 605609.

Rufty T.W., Jackson W.A., Raper C.D. (1982) Inhibition of nitrate assimilation in roots in the presence of ammonium: the moderating influence of potassium. Journal of Experimental Botany 33, 1122-1137.

Santa-María G.E., Danna C.H., Czibener C. (2000) High-affinity potassium transport in barley roots. Ammonium-sensitive and -insensitive pathways. Plant Physiology 123, 297-306.

Schachtman D.P., Shin R. (2007) Nutrient sensing and signaling: NPKS. Annual Review of Plant Biology 58, 47-69.

Scherer H.W., Ahrens G. (1996) Depletion of non-exchangeable $\mathrm{NH}_{4}{ }^{+}-\mathrm{N}$ in the soil—root interface in relation to clay mineral composition and plant species. European Journal of Agronomy 5, 1-7.

Scherer H.W., Mackown C.T., Leggett J.E. (1984) Potassium-ammonium uptake interactions in tobacco seedlings. Journal of Experimental Botany 35, 1060-1070.

This article is protected by copyright. All rights reserved. 
Scheible W.R., Gonzalez-Fontes A., Lauerer M., Muller-Rober B., Caboche M., Stitt M. (1997) Nitrate acts as a signal to induce organic acid metabolism and repress starch metabolism in tobacco. Plant Cell 9, 783-798.

Scheible W.R., Morcuende R., Czechowski T., Fritz C., Osuna D., Palacios-Rojas N., ..., Stitt M. (2004) Genome-wide reprogramming of primary and secondary metabolism, protein synthesis, cellular growth processes, and the regulatory infrastructure of Arabidopsis in response to nitrogen. Plant Physiology 136, 2483-2499.

Schurr U., Schulze E.D. (1995) The concentration of xylem sap constituents in root exudate, and in sap from intact, transpiring castor bean plants (Ricinus communis L.). Plant, Cell \& Environment 18, 409-420.

Shin R. (2011) Transcriptional regulatory components responding to macronutrient limitation. Journal of Plant Biology 54, 286-293.

Shin R., Berg R.H., Schachtman D.P. (2005) Reactive oxygen species and root hairs in Arabidopsis root response to nitrogen, phosphorus and potassium deficiency. Plant and Cell Physiology 46, 1350-1357.

Shin R., Schachtman D.P. (2004) Hydrogen peroxide mediates plant root cell response to nutrient deprivation. Proceedings of the National Academy of Sciences, USA 101, 8827 8832.

Siebrecht S., Herdel K., Schurr U., Tischner R. (2003) Nutrient translocation in the xylem of poplar-diurnal variations and spatial distribution along the shoot axis. Planta 217, 783793.

Siebrecht S., Tischner R. (1999) Changes in the xylem exudate composition of poplar (Populus tremula x P. alba)—dependent on the nitrogen and potassium supply. Journal of Experimental Botany 50, 1797-1806.

This article is protected by copyright. All rights reserved. 
Smith R.C., Epstein E. (1964) Ion absorption by shoot tissue: kinetics of potassium and rubidium absorption by corn leaf tissue. Plant Physiology 39, 992.

Smirnoff N., Stewart G.R. (1985) Nitrate assimilation and translocation by higher plants: comparative physiology and ecological consequences. Physiologia Plantarum 64, 133140.

Sorger G.J., Ford R.E., Evans H.J. (1965) Effects of univalent cations on the immunoelectrophoretic behavior of pyruvic kinase. Proceedings of the National Academy of Sciences, USA 54, 1614-1621.

Spalding E.P., Hirsch R.E., Lewis D.R., Qi Z., Sussman M.R., Lewis B.D. (1999) Potassium uptake supporting plant growth in the absence of AKT1 channel activity. Inhibition by ammonium and stimulation by sodium. Journal of General Physiology 113, 909-918.

Sun J., Bankston J.R., Payandeh J., Hinds T.R., Zagotta W.N., Zheng N. (2014) Crystal structure of the plant dual-affinity nitrate transporter NRT1. 1. Nature 507, 73-77.

Szczerba M.W., Britto D.T., Balkos K.D., Kronzucker H.J. (2008a) Alleviation of rapid, futile ammonium cycling at the plasma membrane by potassium reveals $\mathrm{K}^{+}$-sensitive andinsensitive components of $\mathrm{NH}_{4}{ }^{+}$transport. Journal of Experimental Botany 59, 303-313.

Szczerba M.W., Britto D.T., Ali S.A., Balkos K.D., Kronzucker H.J. (2008b) $\mathrm{NH}_{4}{ }^{+}$-stimulated and-inhibited components of $\mathrm{K}^{+}$transport in rice (Oryza sativa L.). Journal of Experimental Botany 59, 3415-3423.

Szczerba M.W., Britto D.T., Kronzucker H.J. (2009) K ${ }^{+}$transport in plants: physiology and molecular biology. Journal of Plant Physiology 166, 447-466.

Takei K., Takahashi T., Sugiyama T., Yamaya T., Sakakibara H. (2002) Multiple routes communicating nitrogen availability from roots to shoots: a signal transduction pathway mediated by cytokinin. Journal of Experimental Botany 53, 971-977.

This article is protected by copyright. All rights reserved. 
Takei K., Ueda N., Aoki K., Kuromori T., Hirayama T., Shinozaki K., .., Sakakibara H. (2004) AtIPT3 is a key determinant of nitrate-dependent cytokinin biosynthesis in Arabidopsis. Plant and Cell Physiology 45, 1053-1062.

ten Hoopen F., Cuin T.A., Pedas P., Hegelund J.N., Shabala S., Schjoerring J.K., Jahn T.P. (2010) Competition between uptake of ammonium and potassium in barley and Arabidopsis roots: molecular mechanisms and physiological consequences. Journal of Experimental Botany 61, 2303-2315.

Taochy C., Gaillard I., Ipotesi E., Oomen R., Leonhardt N., Zimmermann S., ..., Boyer J.C. (2015) The Arabidopsis root stele transporter NPF2. 3 contributes to nitrate translocation to shoots under salt stress. Plant Journal 83, 466-479.

Topa M.A., Jackson W.A. (1988) Influence of ambient ammonium on net potassium uptake by decapitated maize seedlings. New Phytologist 110, 135-141.

Torres M.A., Dangl J.L. (2005) Functions of the respiratory burst oxidase in biotic interactions, abiotic stress and development. Current Opinion in Plant Biology 8, 397-403.

Touraine B., Grignon C. (1982) Energetic coupling of nitrate secretion into the xylem of corn roots. Physiologie Vegetale 20, 33-39.

Touraine B., Grignon N., Grignon C. (1988) Charge balance in $\mathrm{NO}_{3}{ }^{-}$fed soybean estimation of $\mathrm{K}^{+}$and carboxylate recirculation. Plant Physiology 88, 605-612.

Touraine B., Grignon N., Grignon C. (1990) Interaction between nitrate assimilation in shoots and nitrate uptake by roots of soybean (Glycine max). Plant and Soil 124, 169-174.

Tsay Y-F., Ho C-H., Chen H-Y., Lin S-H. (2011) Integration of nitrogen and potassium signaling. Annual Review of Plant Biology 62, 207-226.

This article is protected by copyright. All rights reserved. 
Ullrich W.R., Larsson M., Larsson C.M., Lesch S., Novacky A. (1984) Ammonium uptake in Lemna gibba $\mathrm{G} 1$, related membrane potential changes, and inhibition of anion uptake. Physiologia Plantarum 61, 369-376.

Ullrich C.I., Novacky A.J. (1990) Extra-and intracellular pH and membrane potential changes induced by $\mathrm{K}^{+}, \mathrm{Cl}^{-}, \mathrm{H}_{2} \mathrm{PO}_{4}{ }^{-}$, and $\mathrm{NO}_{3}{ }^{-}$uptake and fusicoccin in root hairs of Limnobium stoloniferum. Plant Physiology 94, 1561-1567.

Vale F.R., Jackson W.A., Volk R.J. (1987) Potassium influx into maize root systems influence of root potassium concentration and ambient ammonium. Plant Physiology 84, 1416-1420.

Vale F.R., Volk R.J., Jackson W.A. (1988) Simultaneous influx of ammonium and potassium into maize roots: kinetics and interactions. Planta 173, 424-431.

Van Beusichem M.L., Kirkby E.A., Baas R. (1988) Influence of nitrate and ammonium nutrition on the uptake, assimilation, and distribution of nutrients in Ricinus communis. Plant Physiology 86, 914-921.

Van Egmond F. (1978) Nitrogen nutritional aspects of the ionic balance of plants. In Nitrogen in the Environment, Vol. 2: Soil-Plant-Nitrogen Relationships (eds D. R. E. Nielsen, J. G. MacDonald), pp. 171-189. Academic Press, New York.

Vermeulen S.J., Campbell B.M., Ingram J.S.I. (2012) Climate change and food systems. Annual Review of Environment and Resources 37, 195-222.

Walker D.J., Leigh R.A, Miller AJ. (1996) Potassium homeostasis in vacuolate plant cells. Proceedings of the National Academy of Sciences, USA 93, 10510-10514.

Wang M.Y., Siddiqi M.Y., Glass A.D.M. (1996) Interactions between $\mathrm{K}^{+}$and $\mathrm{NH}_{4}{ }^{+}$: effects on ion uptake by rice roots. Plant, Cell \& Environment 19, 1037-1046.

Wang M.Y, Siddiqi M.Y., Ruth T.J., Glass A.D.M. (1993) Ammonium uptake by rice roots. II. Kinetics of ${ }^{13} \mathrm{NH}_{4}{ }^{+}$influx across the plasmalemma. Plant Physiology 103, 1259-1267. 
Wang M.Y., Glass A.D.M., Shaff J.E., Kochian L.V. (1994) Ammonium uptake by rice roots (III. Electrophysiology). Plant Physiology 104, 899-906.

Wang R., Liu D., Crawford N.M. (1998) The Arabidopsis CHL1 protein plays a major role in high-affinity nitrate uptake. Proceedings of the National Academy of Sciences, USA 95, 15134-15139.

Wang Y.H., Garvin D.F., Kochian L.V. (2001). Nitrate-induced genes in tomato roots. Array analysis reveals novel genes that may play a role in nitrogen nutrition. Plant Physiology 127, 345-359.

Wang Y.Y., Hsu P.K., Tsay Y.F. (2012) Uptake, allocation and signaling of nitrate. Trends in Plant Science 17, 458-467.

Wang R., Tischner R., Gutiérrez R. A., Hoffman M., Xing X., Chen M., ..., Crawford N.M. (2004) Genomic analysis of the nitrate response using a nitrate reductase-null mutant of Arabidopsis. Plant Physiology 136, 2512-2522.

Wang Y., Wu W-H. (2013) Potassium transport and signaling in higher plants. Annual Review of Plant Biology 64, 451-476.

White P.J. (2013) Improving potassium acquisition and utilisation by crop plants. Journal of Plant Nutrition and Soil Science 176, 305-316.

Wolt J.D. (1994) Soil solution chemistry: applications to environmental science and agriculture. John Wiley and Sons.

Wyn Jones R.G., Pollard A. (1983) Proteins, enzymes and inorganic ions. Encyclopedia of Plant Physiology 15B, 528-562.

Xia X., Fan X., Wei J., Feng H., Qu H., Xie D., ..., Xu G. (2015) Rice nitrate transporter OsNPF2.4 functions in low-affinity acquisition and long-distance transport. Journal of Experimental Botany 66, 317-331.

This article is protected by copyright. All rights reserved. 
Xu G., Fan X., Miller A.J. (2012) Plant nitrogen assimilation and use efficiency. Annual Review of Plant Biology 63, 153-182.

Xu G., Wolf S., Kafkafi U. (2002) Ammonium on potassium interaction in sweet pepper. Journal of Plant Nutrition 25, 719-734.

Xu J., Li H.D., Chen L.Q., Wang Y., Liu L.L., He L., Wu W.H. (2006) A protein kinase, interacting with two calcineurin B-like proteins, regulates $\mathrm{K}^{+}$transporter AKT1 in Arabidopsis. Cell 125, 1347-1360.

Zhang F., Niu J., Zhang W., Chen X., Li C., Yuan L., Xie J. (2010) Potassium nutrition of crops under varied regimes of nitrogen supply. Plant and Soil 335, 21-34.

Zsoldos F., Haunold E., Herger P., Vasfaegyi A. (2006) Effects of sulfate and nitrate on $\mathrm{K}^{+}$ uptake and growth of wheat and cucumber. Physiologia Plantarum 80, 425-430.

This article is protected by copyright. All rights reserved. 

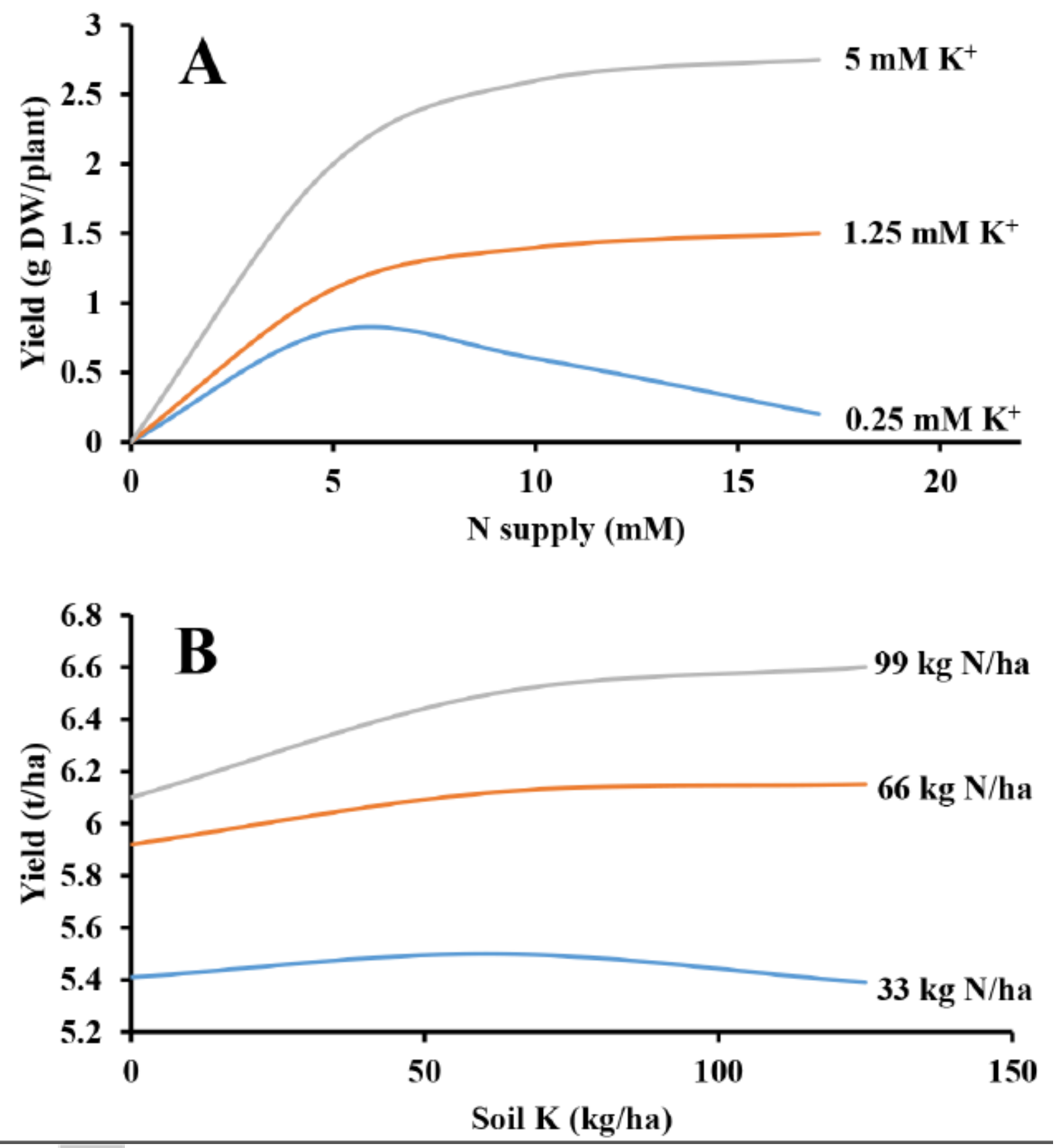

Fig 1

This article is protected by copyright. All rights reserved. 


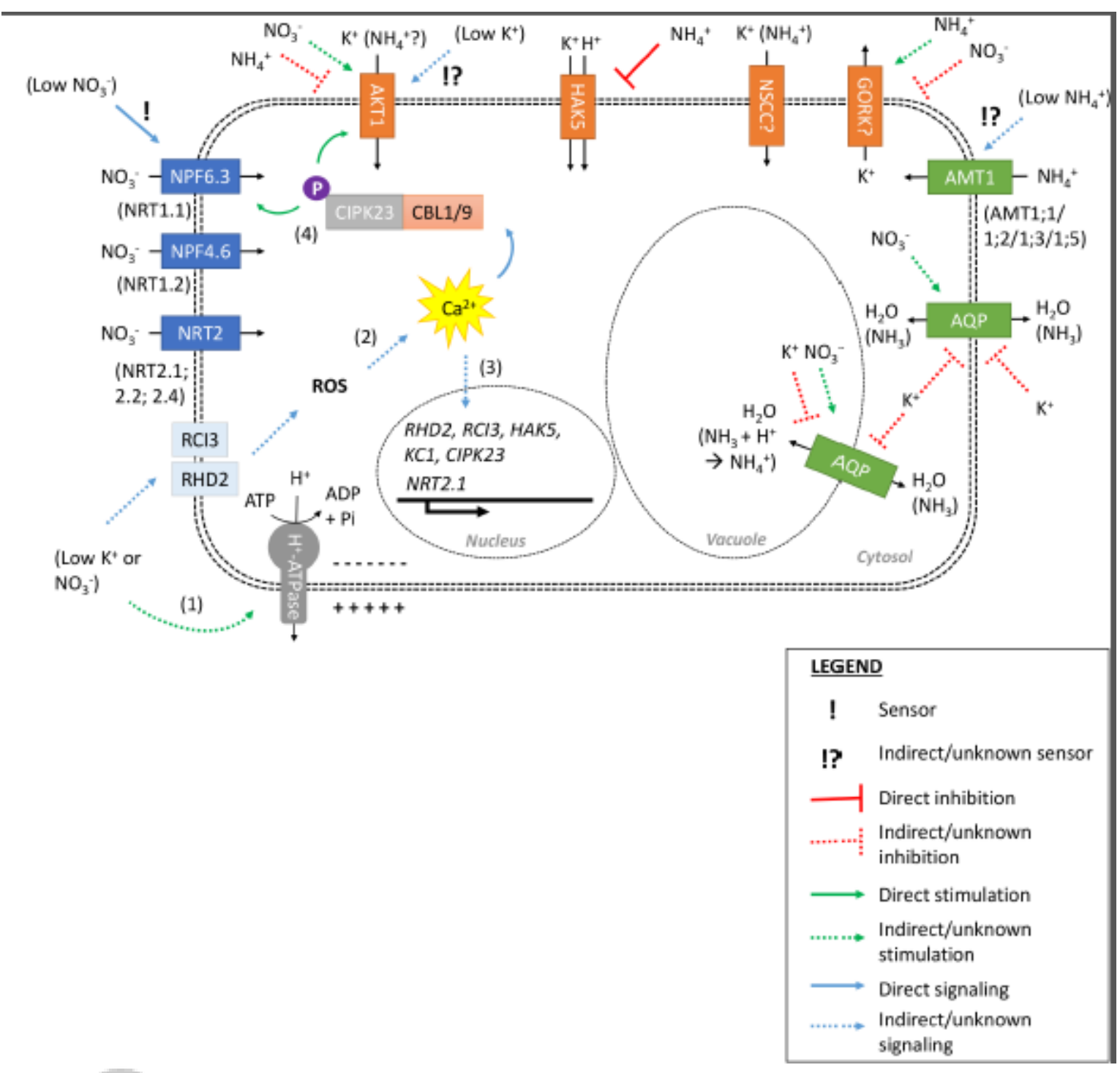

Fig 2

This article is protected by copyright. All rights reserved. 


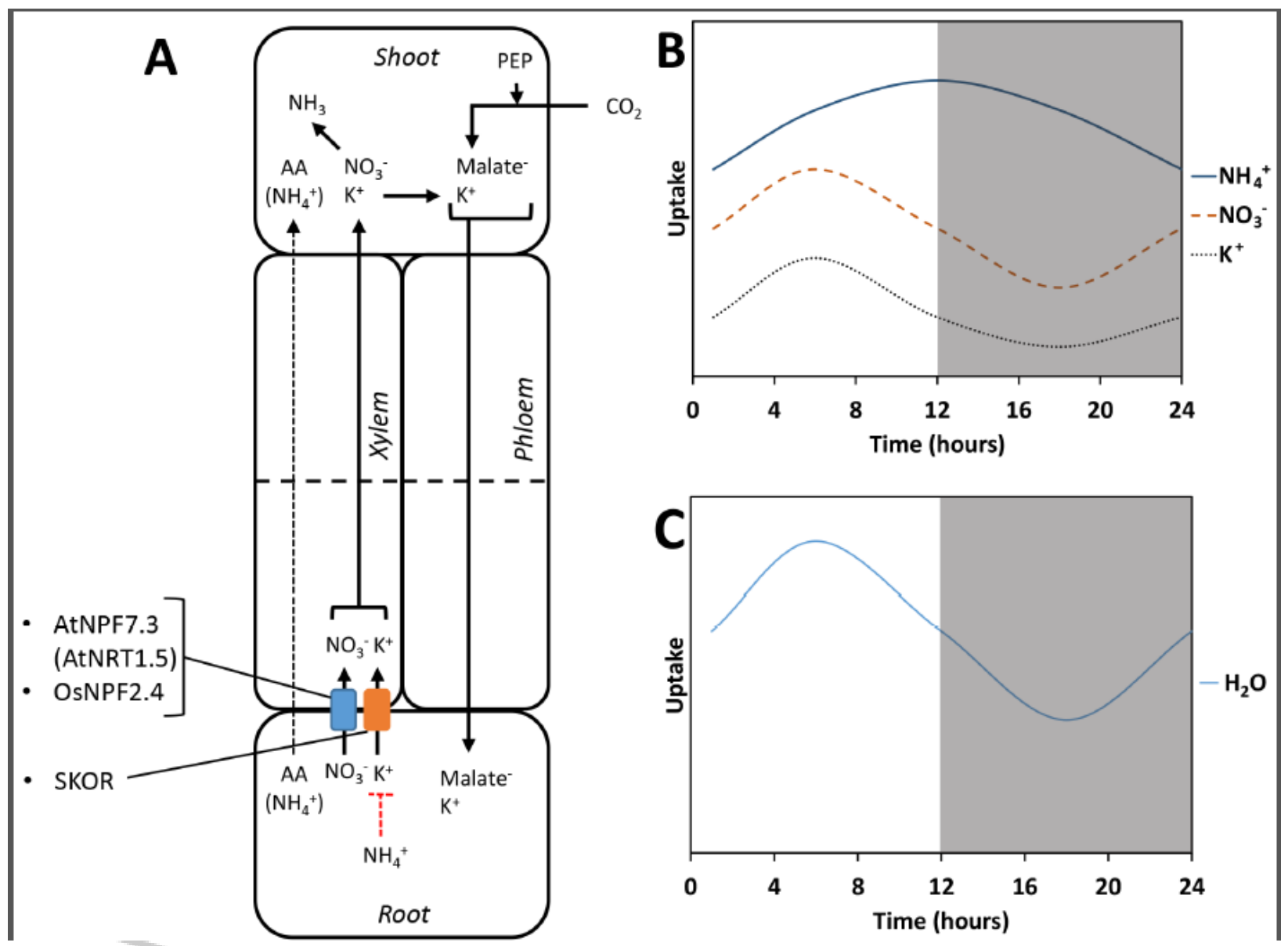

Fig 3

This article is protected by copyright. All rights reserved. 


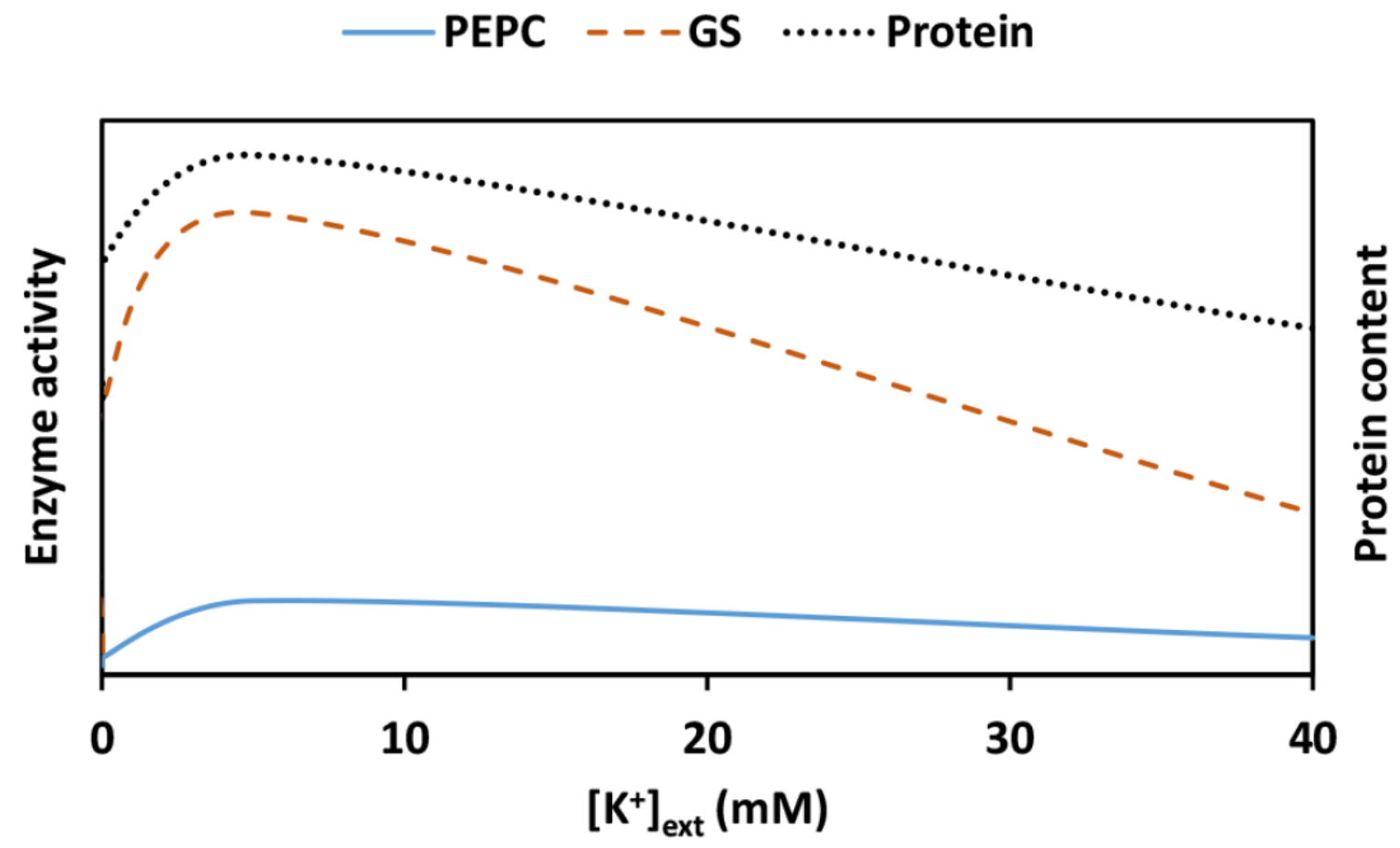

Fig 4

This article is protected by copyright. All rights reserved. 
This review summarizes fundamental intersections between the pathways of inorganic nitrogen ( $\mathrm{NH} 4+$ and $\mathrm{NO} 3$ ) and potassium $(\mathrm{K}+$ ) acquisition in plants. Uptake, storage, translocation, and metabolism are discussed at levels of organization ranging from molecular-genetic processes to whole-plant physiology. The regulation and optimization of plant growth, yield, metabolism, and water-use efficiency are discussed in this nutritional context.

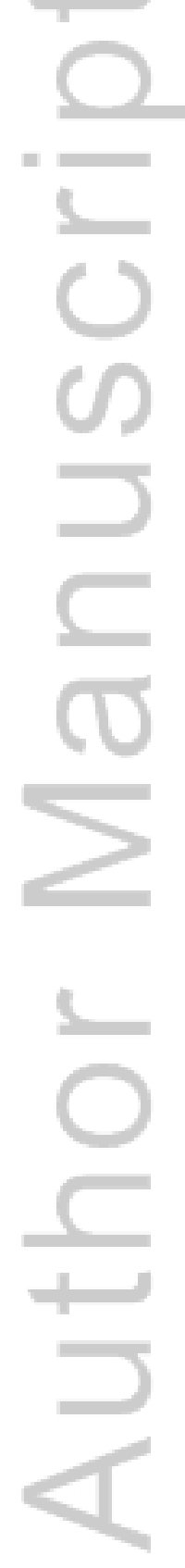

This article is protected by copyright. All rights reserved. 


\section{University Library}

\section{- M M I N E R VA A gateway to Melbourne's research publications}

Minerva Access is the Institutional Repository of The University of Melbourne

Author/s:

Coskun, D;Britto, DT;Kronzucker, HJ

Title:

The nitrogen-potassium intersection: membranes, metabolism, and mechanism

Date:

2017-10-01

Citation:

Coskun, D., Britto, D. T. \& Kronzucker, H. J. (2017). The nitrogen-potassium intersection: membranes, metabolism, and mechanism. PLANT CELL AND ENVIRONMENT, 40 (10), pp.2029-2041. https://doi.org/10.1111/pce.12671.

Persistent Link:

http://hdl.handle.net/11343/290842 